Bilas Volodymyra R., Popadynets' Oleksandr O., Flyunt Igor-Severyn S., Sydoruk Nadiya O., Badiuk Nataliya S., Gushcha Serhiy G., Zukow Walery, Gozhenko Anatoliy I., Popovych Igor L. Entropies of thymocytogram, splenocytogram, immunocytogram and leukocytogram in rats are regulated by sex and the neuroendocrine parameters while regulates immune parameters. Journal of Education, Health and Sport. 2020;10(7):266-288. eISSN 2391-8306. DOI http://dx.doi.org/10.12775/JEHS.2020.10.07.031 https://apcz.umk.pl/czasopisma/index.php/JEHS/article/view/JEHS.2020.10.07.031 https://zenodo.org/record/3978502

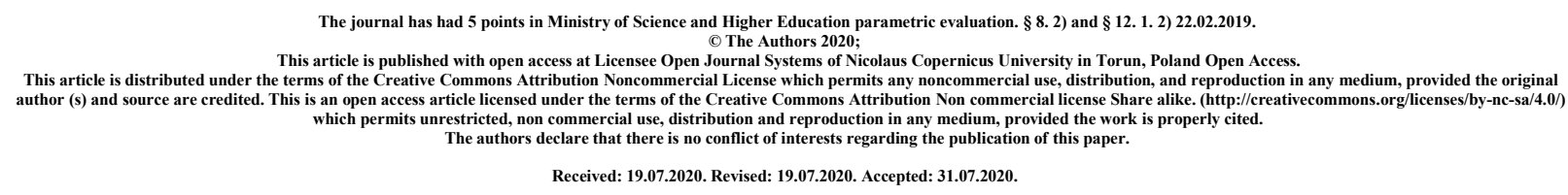

\title{
Entropies of thymocytogram, splenocytogram, immunocytogram and leukocytogram in rats are regulated by sex and the neuroendocrine
} parameters while regulates immune parameters

\author{
Volodymyra R. Bilas ${ }^{1,2}$, Oleksandr O. Popadynets', Igor-Severyn S. Flyunt ${ }^{3}$, \\ Nadiya O. Sydoruk ${ }^{1}$, Nataliya S. Badiuk ${ }^{1}$, Serhiy G. Gushcha ${ }^{4}$, Walery Zukow ${ }^{5}$, Anatoliy I. \\ Gozhenko', Igor L. Popovych ${ }^{2}$ \\ ${ }^{1}$ State Enterprise Ukrainian Research Institute for Medicine of Transport, Odesa, Ukraine \\ bilas1940@gmail.com; prof.gozhenko@gmail.com \\ ${ }^{2}$ OO Bohomolets' Institute of Physiology, Kyïv, Ukraine i.popovych@biph.kiev.ua \\ ${ }^{3}$ Ivan Franko State Pedagogical University, Drohobych, Ukraine igorf3007@ukr.net \\ ${ }^{4}$ State Enterprise Ukrainian Research Institute of Medical Rehabilitation and Kurortology, \\ Odesa, Ukraine mrik@kurort.odessa.net \\ ${ }^{5}$ Nicolaus Copernicus University, Torun, Poland w.zukow@wp.pl
}

\begin{abstract}
Background. We have previously shown that the Entropy (E) of the relative spectral power density (SPD) of the EEG rhythms is its quite relevant parameter. We also found significant relationships between the SPD E of individual EEG loci and the E of the Leukocytogram (LCG) and Immunocytogram (ICG) of the blood, as well as with their individual components. The purpose of this study was to clarify the relationships between $\mathrm{E}(\mathrm{s})$ of these four morphofunctional immune subsystem and sex as well as parameters of the neuroendocrine-immune complex in rats. Materials and methods. Experiment was performed on 108 healthy Wistar rats (48 male and 60 female) weighing 205-300 g ( $\pm \mathrm{SD}=260 \pm 26 \mathrm{~g})$ divided into 8 groups. Animals of the first group remained intact, using tap water from drinking ad libitum. Instead, the other rats received various balneofactors for 6 days. The day after the completion of the drinking/application course in all rats the parameters of neuroendocrine-immune complex were registered. Results. The drinking/application course did not affect the E level of any morphofunctional immune subsystem, the relationships between which are insignificant. Females have less E TCG than males, whereas sexual dimorphism is insignificant for E SCG and ICG and absent for E LCG. The canonical correlation of mediocre force $(\mathrm{R}=0,675)$ between sex index $(\mathrm{M}=1 ; \mathrm{F}=2)$ and neuro-endocrine parameters (HRV, calcitonin, parathyroid and mineralocorticoid
\end{abstract}


activities, corticosterone plasma, 17-KS urine) was revealed. Factors linked to female sex upregulates nine immune parameters $(\mathrm{R}=0,630)$, while downregulates nine others $(\mathrm{R}=0,678)$. The neuroendocrine constellation (testosterone plasma, HRV, calcitonin, parathyroid and mineralocorticoid activities) is associated with the constellation of entropies $(\mathrm{R}=0,533)$. Entropy of a single morpho-functional immune subsystem is associated with a certain constellation of immune parameters. In particular, E SCG with $12(\mathrm{R}=0,721)$, E TCG with $9(\mathrm{R}=0,615)$, E ICG with $8(\mathrm{R}=0,586)$, E LCG with $12(\mathrm{R}=0,631)$. Conclusion. Entropies of thymocytogram, splenocytogram, immunocytogram and leukocytogram in rats are regulated by sex and the neuroendocrine factors while regulates immune parameters.

Key words: Entropy of thymocytogram, splenocytogram, immunocytogram and leukocytogram, autonomic nervous, endocrine and immune parameters, female and male rats.

\section{INTRODUCTION}

We have previously shown that the Entropy of the relative spectral power density (SPD) of the EEG rhythms is its quite relevant parameter. In particular, judging by the portion of the explained dispersion of the information field of the neuro-immune complex, the Entropy in informativeness prevails over such common EEG parameters as rhythm deviation, rhythm index, its asymmetry and lateralization [31]. In other studies in this series, we found significant relationships between the SPD Entropy of individual EEG loci and the Entropy of the Leukocytogram and Immunocytogram of the blood, their individual components [32-36,55] as well as with parameters of gas-discharge visualization [1].

It is obvious that the Leukocytogram and Immunocytogram of peripheral blood reflect the redistribution of immune cells between bone marrow, thymus, spleen, lymph nodes, as well as non-encapsulated lymphoid tissue of mucous membranes, liver, skin, etc. by controlled migration and recirculation [19].

Due to the practical impossibility of analyzing the cellular composition of immune organs in humans (without punctio [3]), we resorted to an experiment in rats. On the other hand, we did not have the technical ability to record in rats the spectral parameters of EEG and HRV. Instead, it was possible to register the parameters of the autonomic nervous and endocrine systems $[15,21,41,42]$. From a previous study by IL Popovych [38], it is known that the Entropies of these four morpho-functional immune subsystems are virtually unrelated, ie not dependent on each other. Based on this, the purpose of this study was to clarify the relationships between Entropies of these four morpho-functional immune subsystem and sex as well as parameters of the neuroendocrine-immune complex.

\section{MATERIAL AND METHODS}

Experiment was performed on 108 healthy Wistar rats (50 male and 58 female) weighing 205-300 g ( $\pm \mathrm{SD}=260 \pm 26 \mathrm{~g})$ divided into 8 groups. Animals of the first group $(\mathrm{n}=20)$ remained intact, using tap water from drinking ad libitum. Instead, the other rats received the same tap water $(n=18)$ as well as mineral waters Naftussya $(n=20)$, Sophiya $(n=10)$, Hertsa $(n=10)$ and its artificial salt analogue $(\mathrm{n}=10)$ through the tube at a dose of $1,5 \mathrm{~mL} / 100 \mathrm{~g}$ of body mass for 6 days. Another group of rats received together with Naftussya water three applications on the tail of ozokerite ( $\mathrm{t}^{0} 40-42^{0} \mathrm{C}$, duration 30 minutes, every other day) $(\mathrm{n}=10)$, and the last - only ozoketite applications $(\mathrm{n}=10)$. 
The day after the completion of the drinking/application course in all rats, at first, a sample of peripheral blood (by incision of the tip of the tail) was taken for analysis of Leukocytogram (LCG), ie the relative content of lymphocytes (L), monocytes (M), eosinophils (Eo), basophils (Bas), rod-shaped (RN) and segmental (SN) neutrophils. Based on these data, the Entropy of the Leukocytogram (hLCG) was calculated according to the formula derived by IL Popovych [38] on the basis of the classical CE Shannon [48] formula:

$\mathrm{hLCG}=-\left[\mathrm{L} \cdot \log _{2} \mathrm{~L}+\mathrm{M} \bullet \log _{2} \mathrm{M}+\mathrm{Eo} \bullet \log _{2} \mathrm{Eo}+\mathrm{Bas} \bullet \log _{2} \mathrm{Bas}+\mathrm{RN} \bullet \log _{2} \mathrm{RN}+\mathrm{SN} \bullet \log _{2} \mathrm{SN}\right] / \log _{2} 6$.

Then they assessed the state of autonomous regulation. For this purpose, under an easy ether anesthesia, for 15-20 sec ECG was recorded in the lead II, inserting needle electrodes under the skin of the legs, followed by the calculation of the parameters of the HRV: mode (Mo), amplitude of the mode (AMo) and variational swing (MxDMn) as markers of the humoral channel of regulation (circulating catecholamines, steroides, glucagon etc), sympathetic and vagal tones respectively [2].

Animals were then placed in individual chambers with perforated bottom for collecting daily urine.

The experiment was completed by decapitation of rats in order to collect as much blood as possible.

The plasma levels of the hormones of adaptation were determined: corticosterone, triiodothyronine and testosterone (by the ELISA) as well as electrolytes: calcium (by reaction with arsenase III), phosphate (phosphate-molybdate method), sodium and potassium (flamming: photometry), electrolytes were also determined in daily urine. The latter also determined the concentration of 17-ketosteroids (by color reaction with m-dinitrobenzene).

The analyzes were carried out according to the instructions described in the manual $[13,17]$. The analyzers "Tecan" (Oesterreich), "Pointe-180" ("Scientific", USA) and "Reflotron" (Boehringer Mannheim, BRD) were used with appropriate sets and a flamming spectrophotometer "CФ-47".

According to the parameters of electrolyte exchange, hormonal activity was evaluated: parathyroide by coefficients $(\mathrm{Cap} / \mathrm{Pp})^{0,5},(\mathrm{Pu} / \mathrm{Cau})^{0,5}$ and $(\mathrm{Cap} \cdot \mathrm{Pu} / \mathrm{Pp} \cdot \mathrm{Cau})^{0,25}$, calcitonin by coefficients $(1 / \mathrm{Cap} \cdot \mathrm{Pp})^{0,5},(\mathrm{Cau} \cdot \mathrm{Pu})^{0,5}$ and $(\mathrm{Cau} \cdot \mathrm{Pu} / \mathrm{Cap} \cdot \mathrm{Pp})^{0,25}$ as well as mineralocorticoid by coefficients $(\mathrm{Nap} / \mathrm{Kp})^{0,5},(\mathrm{Ku} / \mathrm{Nau})^{0,5}$ and $(\mathrm{Nap} \cdot \mathrm{Ku} / \mathrm{Kp} \cdot \mathrm{Nau})^{0,25}$, based on their classical effects and recommendations by IL Popovych [41,42].

In the blood, the parameters of immunity were determined, as described in the manual [26]: the relative content of the population of T-lymphocytes in a test of spontaneous rosette formation with erythrocytes of sheep by $M$ Jondal et al [18], their theophylline-resistant (T-helper) and theophyllin-susceptible (T-cytolytic) subpopulations (by the test of sensitivity of rosette formation to theophylline by S Limatibul et al [24]; the population of B-lymphocytes by the test of complementary rosette formation with erythrocytes of sheep by $\mathrm{C}$ Bianco [5]. Natural killers were identified as large granules contain lymphocytes. The content of zero-lymphocytes (0L) was calculated by the balance method. For these components, as well as plasma cells (Pla), the Entropy of the Immunocytogram (hICG) was calculated;

$\mathrm{hICG}=-\left[\mathrm{Th} \bullet \log _{2} \mathrm{Th}+\mathrm{Tc} \bullet \log _{2} \mathrm{Tc}+\mathrm{B} \bullet \log _{2} \mathrm{~B}+\mathrm{Pla} \bullet \log _{2} \mathrm{Pla}+\mathrm{NK} \bullet \log _{2} \mathrm{NK}+0 \mathrm{~L} \bullet \log _{2} 0 \mathrm{~L}\right] / \log _{2} 6$.

The blast transformation reaction of T-lymphocytes to phytohemagglutinin was performed separately [26].

About the condition of the phagocytic function of neutrophils (microphages) and monocytes (macrophages) were judged by the phagocytosis index, the microbial count and the killing index 
for Staphylococcus aureus (ATCC N25423 F49). According to these parameters and the content of microphages and macrophages in the blood calculated their bactericidal ability $[6,41]$.

After decapitation, the spleen, thymus and adrenal glands were removed from the animals. In the adrenal glands after weighing, the thickness of glomerular, fascicular reticular and medullar zones was measured under a microscope $[6,41]$.

Immune organs weighed and made smears-imprints for counting Thymocytogram and Splenocytogram $[3,4,6]$. The components of the thymocytogram (TCG) are lymphocytes (Lc), lymphoblasts (Lb), reticulocytes (Ret), macrophages (Mac), endotheliocytes (End), epitheliocytes (Epi) and Hassal's corpuscles (Has). The Splenocytogram (SCG) includes lymphocytes (Lc), lymphoblasts (Lb), plasma cells (Pla), reticulocytes (Ret), macrophages (Mac), fibroblasts (Fib), microphages (Mic) and eosinophils (Eos).

For them Shannon's entropy was calculated too:

hTCG $=-\left[\mathrm{Lc} \bullet \log _{2} \mathrm{Lc}+\mathrm{Lb} \bullet \log _{2} \mathrm{Lb}+\right.$ Ret $\bullet \log _{2}$ Ret $+\mathrm{Mac} \bullet \log _{2} \mathrm{Mac}+\mathrm{En} \bullet \log _{2}$ En+Ep $\bullet \log _{2}$ Ep + Has $\left.\bullet \log _{2} \mathrm{Has}\right] / \log _{2} 7$

$\mathrm{hSCG}=-\left[\mathrm{Lc} \bullet \log _{2} \mathrm{Lc}+\mathrm{Lb} \bullet \log _{2} \mathrm{Lb}+\mathrm{P} \bullet \log _{2} \mathrm{P}+\mathrm{R} \bullet \log _{2} \mathrm{R}+\mathrm{Ma} \bullet \log _{2} \mathrm{Ma}+\mathrm{F} \bullet \log _{2} \mathrm{~F}+\mathrm{Mi} \bullet \log _{2} \mathrm{Mi}+\mathrm{Eo} \bullet \log _{2} \mathrm{Eo}\right] / \log _{2} 8$

Digital material is statistically processed on a computer using the software package "Statistica 8.0".

\section{RESULTS AND DISCUSION}

The calculation of the Entropy of the peripheral blood Immunocytogram, as well as the Splenocytogram and Thymocytogram of smear prints in rats was first used by IL Popovych in 2007 [38], using the idea of OG Yushkovs'ka [51] to use the calculation of the Entropy of Leukocytogram of peripheral blood in athletes for estimation their adaptive responses. The creativity of this approach is demonstrated in subsequent studies by IL Popovych et al $[10,14,16,21-23,25,29,30,39,40,43-47,49,50,52-54]$ and other representatives of the Truskavetsian Scientific School [11,12,20,37]. However, Entropy was not the focus of the analysis it occupied in this study.

In the first stage of the analysis, we find out the sex differences in the Entropy of cytograms. To enable a quantitative assessment of the role of sex, males were given conditionally one point, and females two points.

Fig. 1 illustrates the significant sexual dimorphism of the Entropy cytogram of the central organ of immune system, which is documented by the correlation coefficient between Entropy and sex index. 


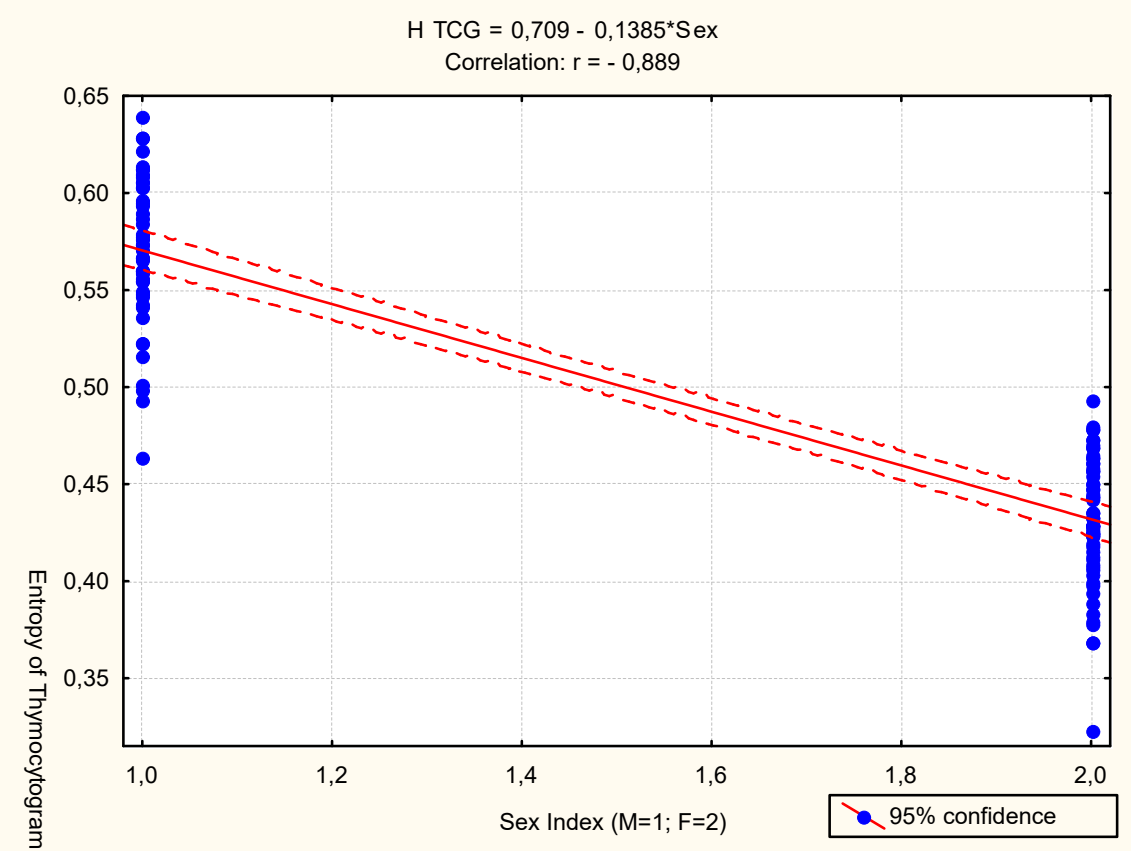

Fig. 1. Sex differences Thymocytogram entropy in rats

However, with respect to the Splenocytogram (Fig. 2) and the Immunocytogram (Fig. 3), the sex differences are insignificant, and with respect to the Leukocytogram (Fig. 4) they are completely absent (although different variance draws attention).

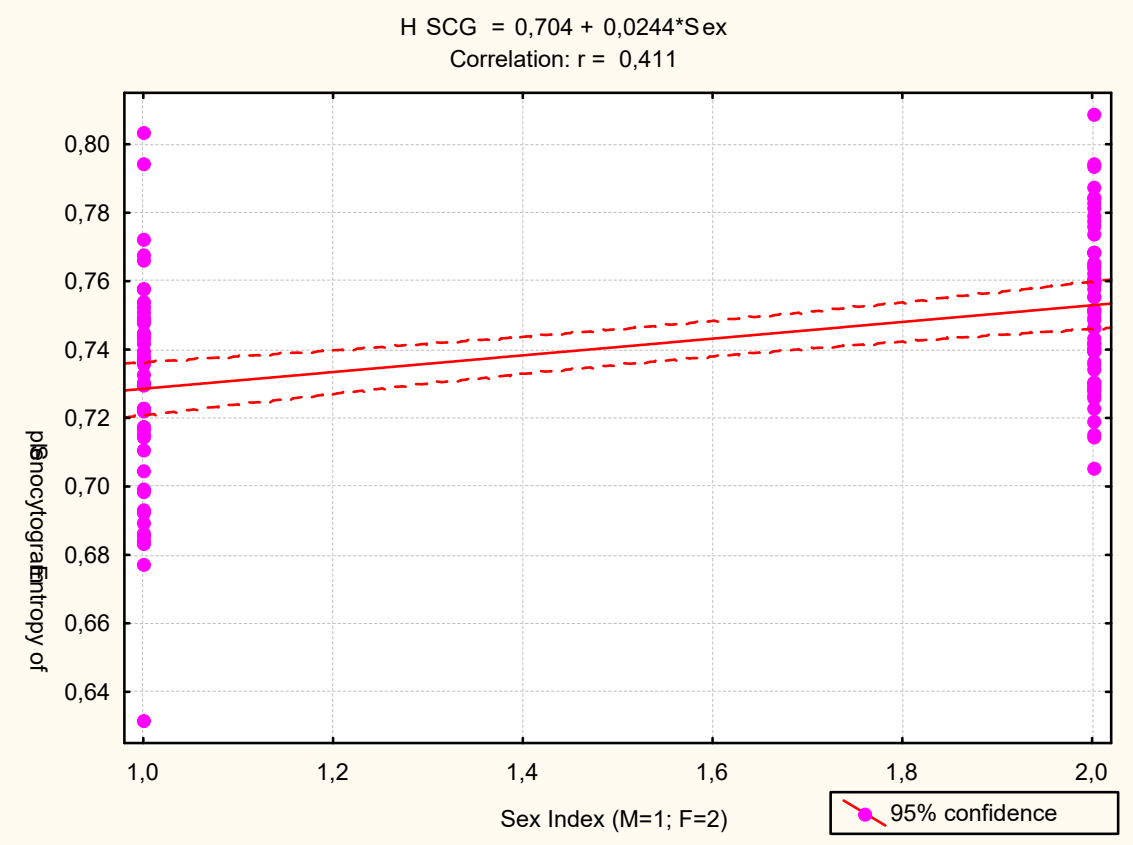

Fig. 2. Sex differences Splenocytogram entropy in rats 


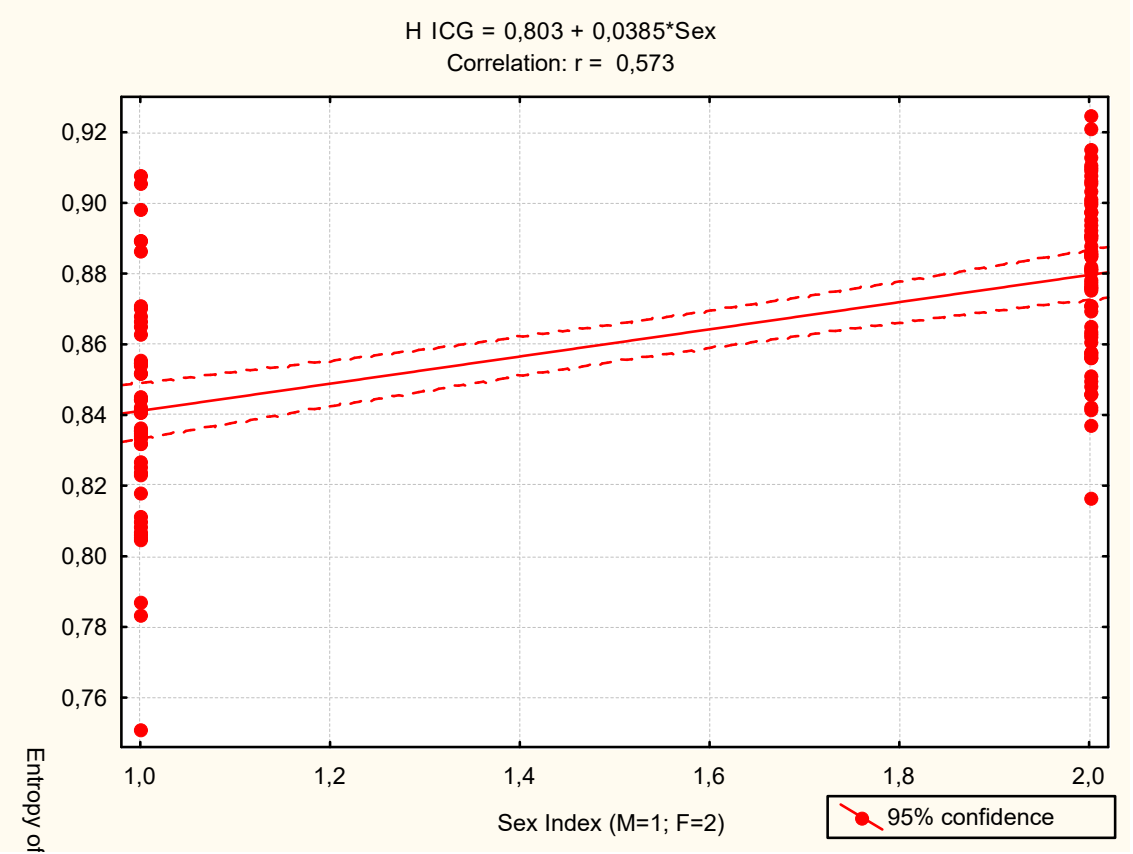

Fig. 3. Sex differences Immunocytogram entropy in rats

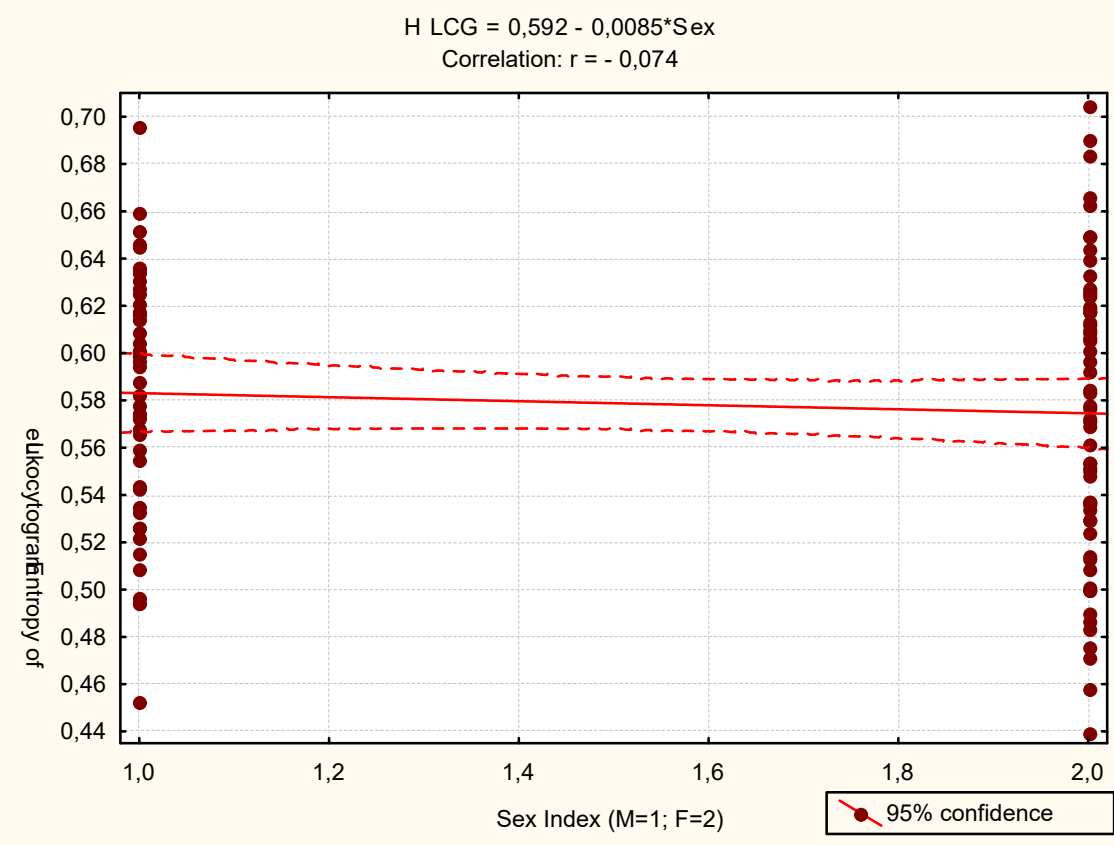

Fig. 4. Sex differences Leukocytogram entropy in rats

Given the information about the presence of sexual dimorphism in a number of parameters of the neuroendocrine-immune complex of rats [46], in order to level it, all registered parameters were calculated in Z-scores, ie normalized. Figures 5-8 illustrate the leveling (along the Y axis) of sex differences of cytograms of morpho-functional immune subsystems. 


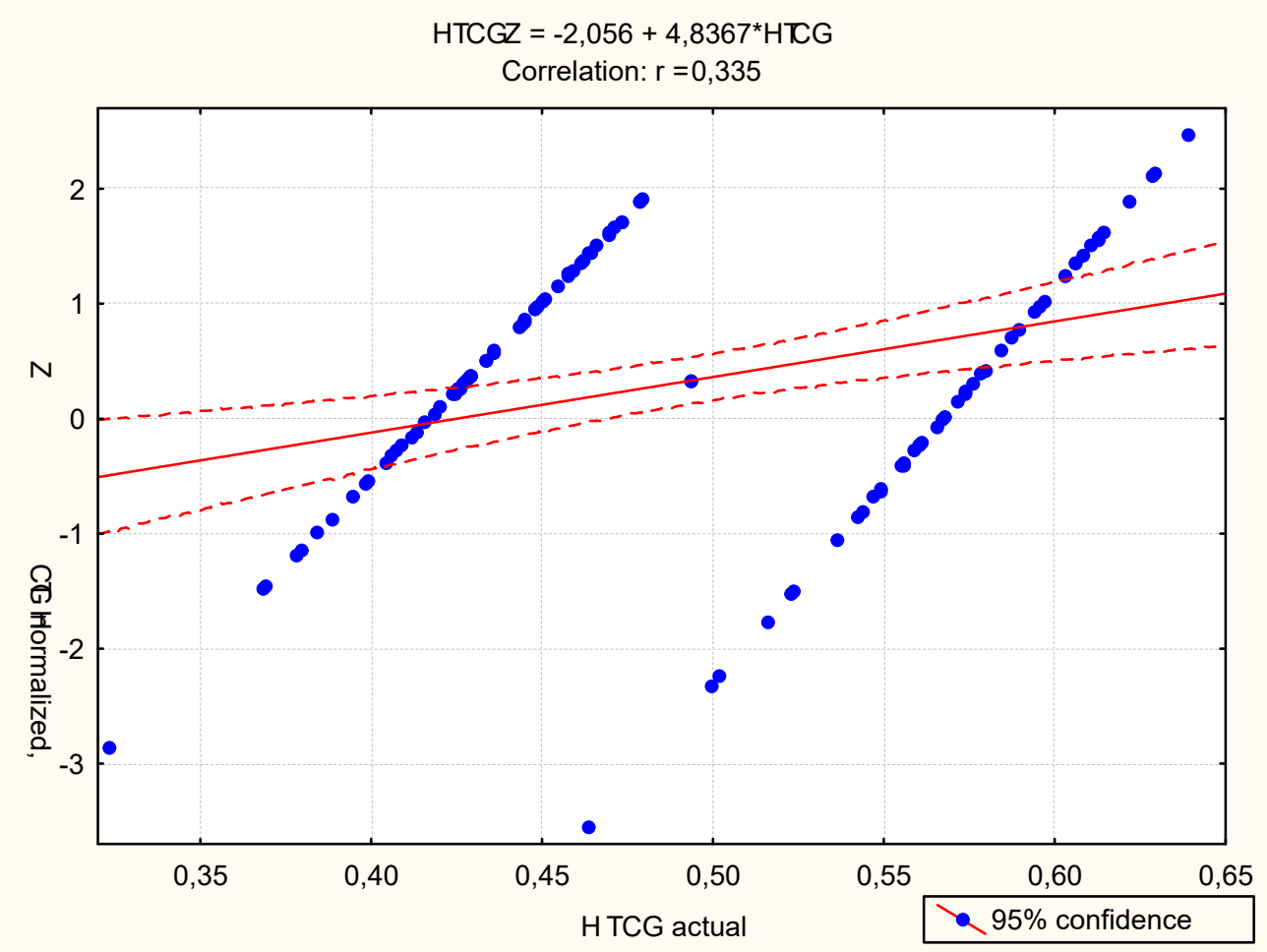

Fig. 5. Actual (X-axis) and normalized (Y-axis) values of Entropy Thymocytogram of rats of both sexes

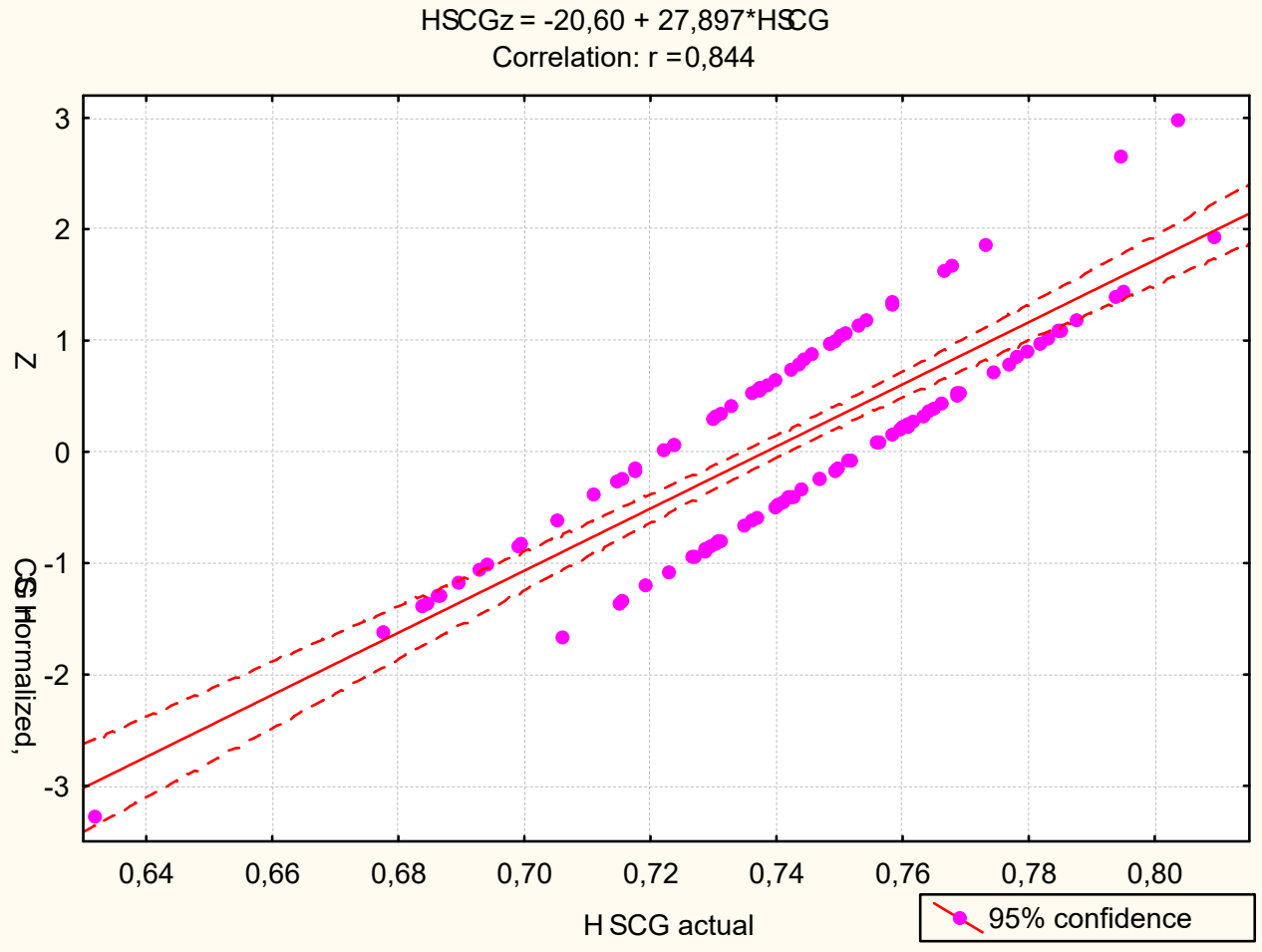


Fig. 6. Actual (X-axis) and normalized (Y-axis) values of Entropy Splenocytogram of rats of both sexes

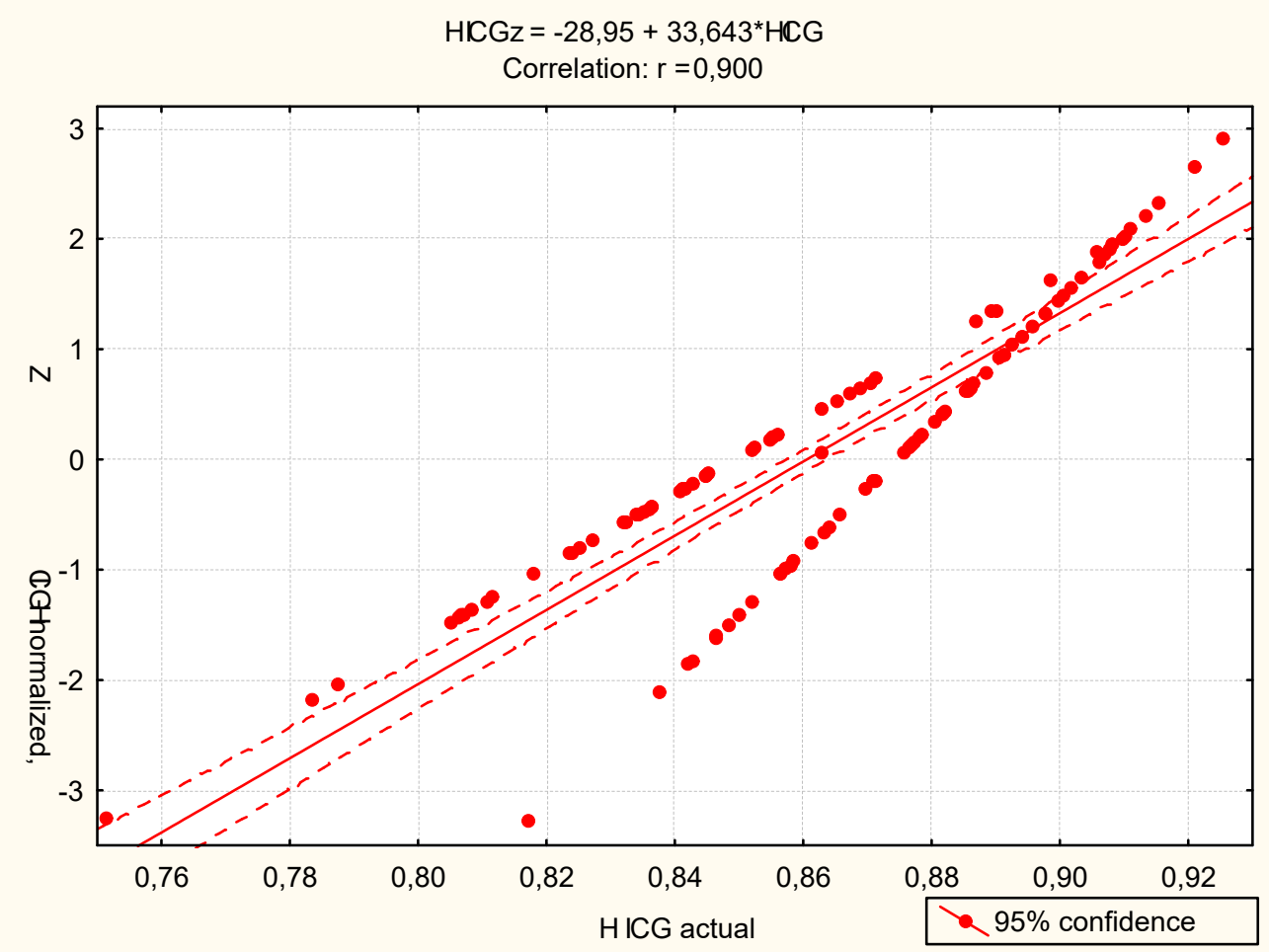

Fig. 7. Actual (X-axis) and normalized (Y-axis) values of Entropy Immunocytogram of rats of both sexes 


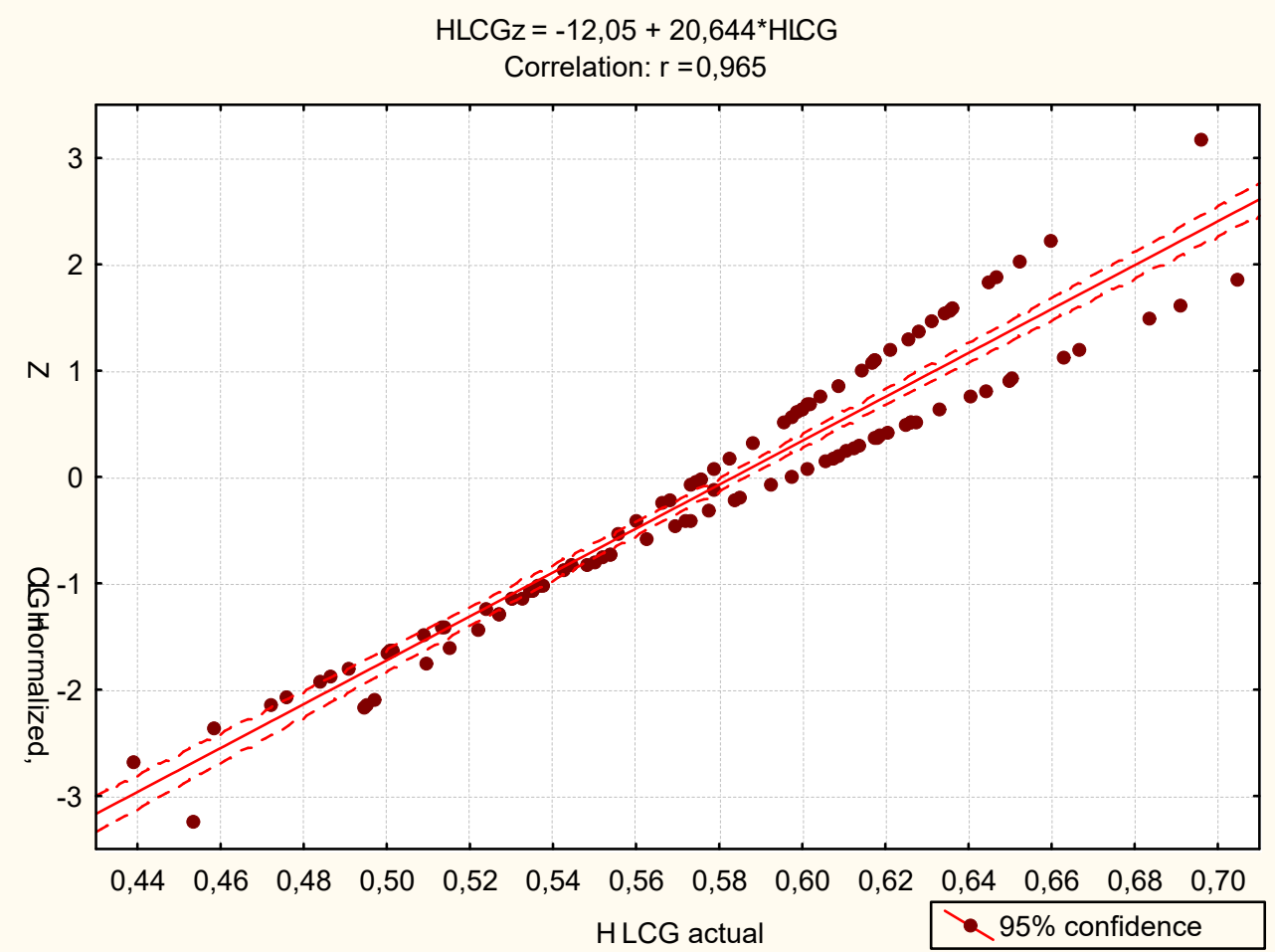

Fig. 8. Actual (X-axis) and normalized (Y-axis) values of Entropy Leukocytogram of rats of both sexes

When comparing the actual Entropy levels of the Thymocytogram, it was found that the applied course of balneofactors, judging by the average values, did not affect them in either males or females (Fig. 9).

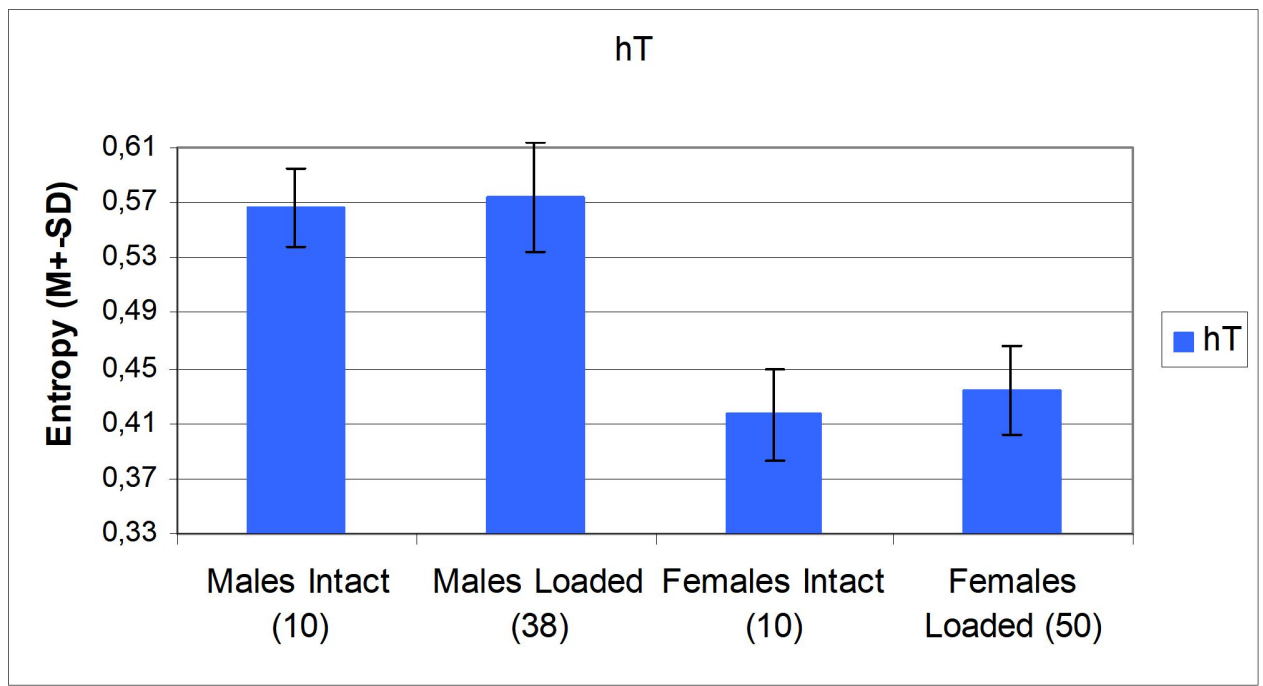

Fig. 9. Actual levels of Thymocytogram entropy in intact and balneo-loaded rats of both sexes

A similar situation occurs with respect to the Entropy levels of the Splenocytogram (Fig. 10), the Immunocytogram (Fig. 11) and the Leukocytogram (Fig. 12). 


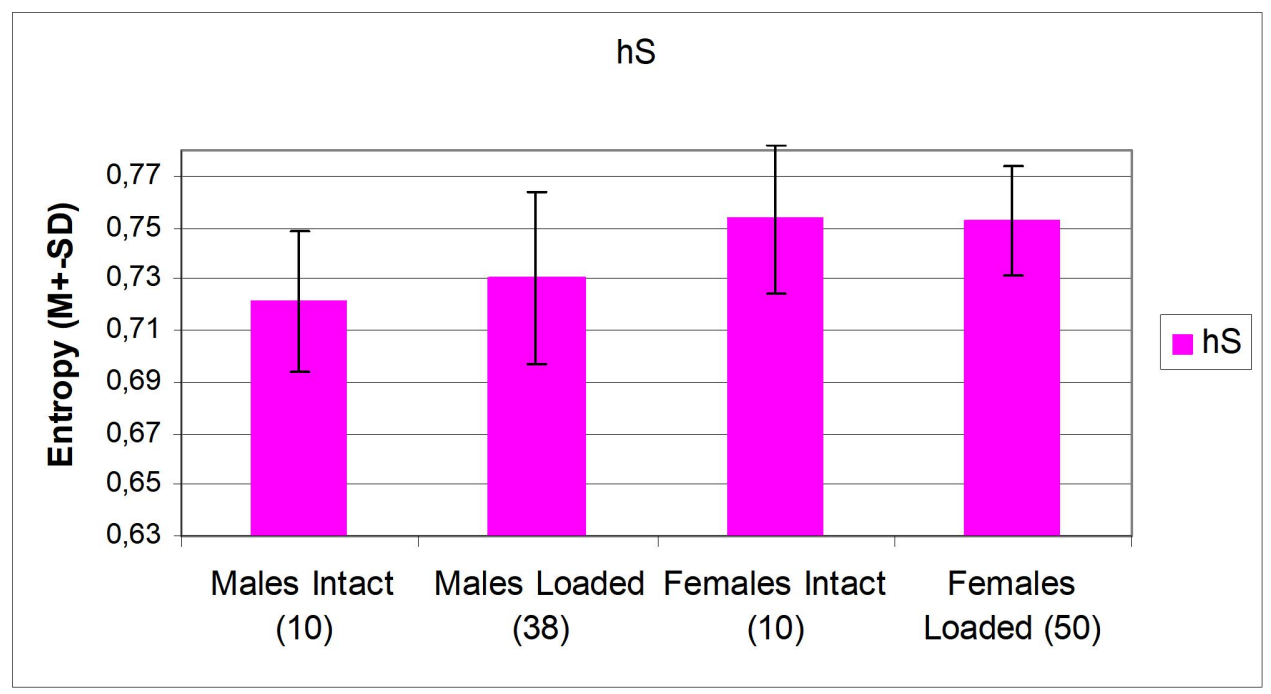

Fig. 10. Actual levels of Splenocytogram entropy in intact and balneo-loaded rats of both sexes

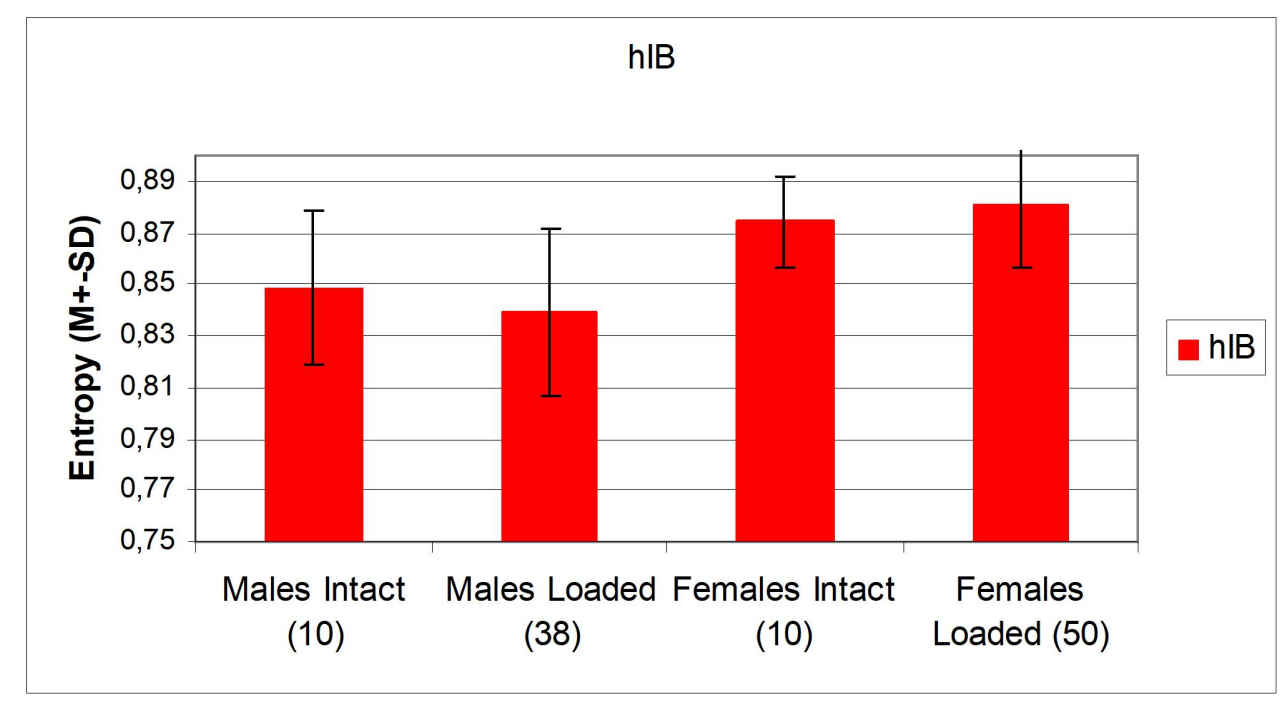

Fig. 11. Actual levels of Immunocytogram entropy in intact and balneo-loaded rats of both sexes 


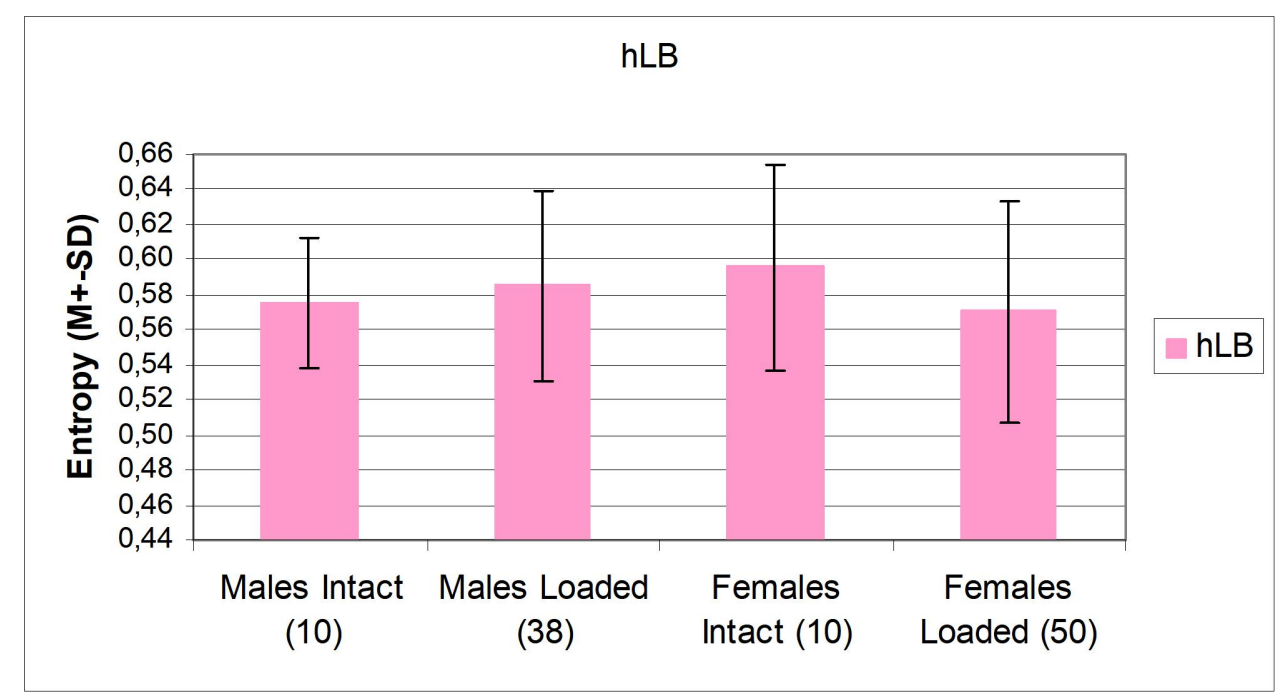

Fig. 12. Actual levels of Leukocytogram entropy in intact and balneo-loaded rats of both sexes

Thus, the Entropy of all four morpho-functional immune subsystems under the conditions of our experiment was found to be stable, in contrast to the actual parameters of the neuroendocrineimmune complex both in rats and humans $[15,37,41,42,50]$.

Based on the screening of correlations of sex index with normalized neuro-endocrine parameters with step-by-step exclusion, a regression model was constructed (Table 1). It was found that sex determines the level of constellation of endocrine parameters by $43 \%$. The negative correlation of the sex index with calcitonin and parathyroid activity and corticosteronemia indicates a lower level in females, while they have higher than in males, mineralocorticoid activity and daily excretion of 17-ketosteroids.

Table 1. Regression Summary for Endocrine Variables vs Sex Index $\mathrm{R}=0,675 ; \mathrm{R}^{2}=0,456 ;$ Adjusted $\mathrm{R}^{2}=0,429 ; \mathrm{F}_{(5,1)}=17,1 ; \mathrm{p}<10^{-5}$

\begin{tabular}{|c|c|c|c|c|c|c|c|}
\hline & & Beta & St. Err. & B & St. Err. & $\mathbf{t}_{(102)}$ & p-level \\
\hline Variables, Z & $\mathbf{r}$ & & Intercpt & 1,347 & 0,045 & 29,9 & $10^{-6}$ \\
\hline$(\text { (Cau•Pu/Cap•Pp) })^{0,25}$ & $-0,59$ & $-0,322$ & 0,097 & $-0,067$ & 0,020 & $-3,33$ & 0,001 \\
\hline$(\text { (Cap•Pu/Cau•Pp) })^{0,25}$ & $-0,40$ & $-0,163$ & 0,085 & $-0,071$ & 0,037 & $-1,92$ & 0,058 \\
\hline Corticosterone Plasma & $-0,22$ & $-0,087$ & 0,075 & $-0,034$ & 0,029 & $-1,16$ & 0,249 \\
\hline$(\mathrm{Nap} / \mathrm{Kp})^{0,5}$ & 0,47 & 0,271 & 0,082 & 0,114 & 0,035 & 3,30 & 0,001 \\
\hline 17-Ketosteroides Urine & 0,31 & 0,181 & 0,076 & 0,064 & 0,027 & 2,38 & 0,019 \\
\hline
\end{tabular}

Among the registered immune parameters, two networks were found, with positive and negative correlation with the sex index. The first set (Table 2) contains 6 parameters of blood, 2 parameters of the spleen and one parameter of the thymus, the levels of which are higher in females, ie subject to upregulation by factors associated with the female sex. Has the right to exist and an alternative statement about the subjectivity of these parameters to the 
downregulation by factors linked to the male sex. Be that as it may, sex determines the level of this immune constellation by $34 \%$.

Table 2. Regression Summary for Upregulated Immune Variables vs Sex Index $\mathrm{R}=0,630 ; \mathrm{R}^{2}=0,397 ;$ Adjusted $\mathrm{R}^{2}=0,342 ; \mathrm{F}_{(10,0)}=7,2 ; \mathrm{p}<10^{-6}$

\begin{tabular}{|l|c|c|c|c|c|c|c|}
\hline \multicolumn{1}{|c|}{} & & Beta & St. Err. & B & St. Err. & $\mathbf{t}_{(\mathbf{9 8})}$ & p-level \\
\hline Variables, Z & $\mathbf{r}$ & & Intercpt & 1,571 & 0,046 & 34,47 & $10^{-6}$ \\
\hline Natural Killers Blood & 0,35 & 0,132 & 0,086 & 0,040 & 0,026 & 1,54 & 0,127 \\
\hline PhI Monocytes Blood & 0,33 & 0,278 & 0,085 & 0,130 & 0,040 & 3,27 & 0,002 \\
\hline Endotheliocytes Thymus & 0,32 & 0,165 & 0,086 & 0,073 & 0,038 & 1,91 & 0,059 \\
\hline Reticulocytes Spleen & 0,30 & 0,231 & 0,083 & 0,112 & 0,040 & 2,79 & 0,006 \\
\hline Killing Ind Neutr Blood & 0,27 & 0,201 & 0,082 & 0,091 & 0,037 & 2,45 & 0,016 \\
\hline Basophiles Blood & 0,26 & 0,193 & 0,102 & 0,090 & 0,047 & 1,89 & 0,061 \\
\hline Lymphoblastes Spleen & 0,26 & 0,113 & 0,085 & 0,054 & 0,041 & 1,33 & 0,189 \\
\hline T-cytolytic Lymph Bloo & 0,22 & 0,153 & 0,098 & 0,069 & 0,044 & 1,57 & 0,121 \\
\hline Plasmocytes Blood & 0,21 & $-0,152$ & 0,113 & $-0,058$ & 0,043 & $-1,35$ & 0,180 \\
\hline
\end{tabular}

Instead, the second set (Table 3) consists of 5 other blood parameters, 2 parameters of the spleen and 2 parameters of the thymus, the levels of which are lower in females, ie subject to downregulation by factors linked to the female sex or activated by factors linked to the male sex. The degree of sex determination of this immune constellation is $41 \%$.

Table 3. Regression Summary for Downregulated Immune Variables vs Sex Index $\mathrm{R}=0,678 ; \mathrm{R}^{2}=0,460 ;$ Adjusted $\mathrm{R}^{2}=0,410 ; \mathrm{F}_{(10,0)}=9,3 ; \mathrm{p}<10^{-6}$

\begin{tabular}{|l|c|c|c|c|c|c|c|c|}
\hline \multicolumn{1}{|l|}{} & \multicolumn{1}{|c|}{ Beta } & St. Err. & B & St. Err. & $\mathbf{t}_{(\mathbf{9 8})}$ & p-level \\
\hline Variables, Z & $\mathbf{r}$ & & Intercpt & 1,644 & 0,046 & 35,90 & $10^{-6}$ \\
\hline Macrophages Thymus & $-0,40$ & $-0,192$ & 0,087 & $-0,050$ & 0,023 & $-2,21$ & 0,029 \\
\hline Monocytes Blood & $-0,39$ & $-0,308$ & 0,076 & $-0,172$ & 0,042 & $-4,05$ & $10^{-4}$ \\
\hline 0-Lymphocytes Blood & $-0,30$ & $-0,103$ & 0,085 & $-0,042$ & 0,034 & $-1,22$ & 0,224 \\
\hline Microbian Count Monocytes Blood & $-0,29$ & $-0,130$ & 0,088 & $-0,031$ & 0,021 & $-1,48$ & 0,143 \\
\hline Thymus Mass Index & $-0,27$ & $-0,179$ & 0,077 & $-0,092$ & 0,040 & $-2,32$ & 0,022 \\
\hline Leukocytes Blood & $-0,26$ & $-0,191$ & 0,075 & $-0,091$ & 0,036 & $-2,54$ & 0,013 \\
\hline Plasmocytes Spleen & $-0,23$ & $-0,160$ & 0,078 & $-0,085$ & 0,042 & $-2,05$ & 0,044 \\
\hline Macrophages Spleen & $-0,22$ & $-0,093$ & 0,081 & $-0,043$ & 0,037 & $-1,15$ & 0,252 \\
\hline Eosinophiles Blood & $-0,20$ & $-0,204$ & 0,078 & $-0,106$ & 0,040 & $-2,62$ & 0,010 \\
\hline
\end{tabular}


In order to assess the integral effect on the Entropy of immune subsystems from neuroendocrine factors, a procedure of canonical correlation analysis was performed. The resulting (right) set is formed of partial Entropies. Within the set, a significant correlation was found only between the Entropies of the Thymocytogram and the Immunocytogram (Table 4). Interestingly, a fairly similar range of intrasystem correlation coefficients $(\mathrm{r}=-0,21 \div 0,06)$ was detected by IL Popovych [] in a completely different sample of 58 rats of both sexes, ie morpho-functional subsystems are sufficiently independent of each other.

\section{Table 4. Matrix of Correlation (Right set)}

\begin{tabular}{|l|l|l|l|l|l|}
\hline Variables, $\mathbf{Z}$ & H LCG & H ICG & H TCG & H SCG \\
\hline Entropy Leukocytogram & 1 & 0,140 & $-0,046$ & 0,078 \\
\hline Entropy Immunocytogram & 0,140 & 1 & $\mathbf{0 , 2 6 5}$ & $-0,183$ \\
\hline Entropy Thymocytogram & $-0,046$ & $\mathbf{0 , 2 6 5}$ & 1 & 0,125 \\
\hline Entropy Splenocytogram & 0,078 & $-0,183$ & 0,125 & 1 \\
\hline
\end{tabular}

The factor (left) set is formed by the parameters of the autonomic nervous system, calcitonin, parathyroid and mineralocorticoid activities, as well as plasma testosterone (Table 5).

Table 5. Matrix of Correlation (Left set vs Right set)

\begin{tabular}{|l|c|c|c|c|c|c|c|c|c|}
\hline Variables, $\mathbf{Z}$ & AMo & DX & Mode & CTAu & PTAu & GloZAC & MCAp & Testost \\
\hline Entropy Leukocytogram & 0,098 & 0,051 & 0,186 & 0,157 & 0,153 & 0,073 & 0,025 & $-0,172$ \\
\hline Entropy Immunocytogram & 0,080 & 0,130 & 0,052 & $-0,189$ & 0,026 & $-0,009$ & $\mathbf{0 , 2 8 4}$ & $\mathbf{0 , 2 0 5}$ \\
\hline Entropy Thymocytogram & $\mathbf{0 , 2 9 4}$ & $\mathbf{- 0 , 2 2 1}$ & $\mathbf{- 0 , 1 9 9}$ & $-0,161$ & $-0,138$ & $-0,014$ & 0,073 & 0,146 \\
\hline Entropy Splenocytogram & 0,155 & $-0,166$ & $-0,170$ & $\mathbf{0 , 1 9 1}$ & $\mathbf{- 0 , 2 0 5}$ & $-0,184$ & $-0,127$ & 0,002 \\
\hline
\end{tabular}

As a result, two pairs of canonical roots were identified (Table 6). The factor root of the first pair, judging by the received moderate negative loadings, represents inversely six endocrine parameters. The effective root of the first pair directly represents the Entropy of the LCG and the ICG, while inversely - the SCG. The canonical correlation between the roots of moderate strength, but significant (Fig. 13). The factor structure of the second pair of canonical roots has both common and distinctive features, compared with that of the first pair. The canonical correlation between the roots is somewhat weaker, but also significant (Fig. 14).

Table 6. Factor Structure Matrix for Canonical Correlation between Endorine parameters (Left set) and Entropies of Morpho-functional Immune Subsystems (Right set)

\begin{tabular}{|l|c|c|}
\hline \multicolumn{1}{|c|}{ Right set } & R 1 & \multicolumn{1}{c|}{ R 2 } \\
\hline Entropy Leukocytogram & $-\mathbf{0 , 9 1 8}$ & $-0,262$ \\
\hline Entropy Splenocytogram & $\mathbf{0 , 1 7 0}$ & $\mathbf{0 , 1 7 5}$ \\
\hline Entropy Immunocytogram & $-\mathbf{0 , 4 1 9}$ & $\mathbf{0 , 7 7 0}$ \\
\hline Entropy Thymocytogram & $-0,182$ & $\mathbf{0 , 6 5 1}$ \\
\hline
\end{tabular}




\begin{tabular}{|l|c|c|}
\hline \multicolumn{1}{|c|}{ Left set } & R 1 & R 2 \\
\hline Mode HRV as Humoral channel & $\mathbf{- 0 , 3 3 8}$ & $-0,335$ \\
\hline (Cap/Pp) $^{\mathbf{0 , 5}}$ as Parathyroid Activity & $\mathbf{- 0 , 3 1 0}$ & $-0,323$ \\
\hline AMo HRV as Sympathetic tone & $\mathbf{- 0 , 2 4 2}$ & $\mathbf{0 , 3 9 5}$ \\
\hline${\text { (Nap/Kp) })^{\mathbf{0 , 5}} \text { as Mineralocorticoid Act }}^{-\mathbf{- 0 , 2 2 9}}$ & $\mathbf{0 , 4 2 7}$ \\
\hline Glomerulary Zone of Adrenal Cortex & $-\mathbf{0 , 1 9 7}$ & $-\mathbf{0 , 2 0 0}$ \\
\hline MxDMn HRV as Vagal tone & $\mathbf{- 0 , 1 2 3}$ & $-0,116$ \\
\hline (Cau•Pu $^{\mathbf{0}, 5}$ as Calcitonin Activity & $-0,058$ & $\mathbf{- 0 , 4 5 0}$ \\
\hline Testosterone plasma & 0,168 & $\mathbf{0 , 5 9 7}$ \\
\hline
\end{tabular}

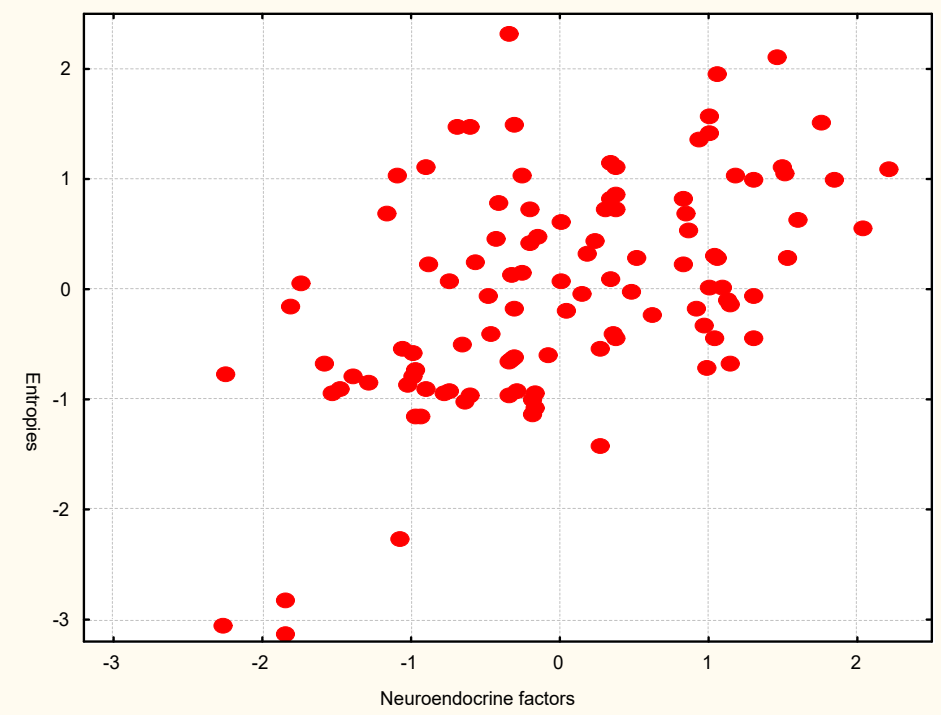

$\mathrm{R}=0,533 ; \mathrm{R}^{2}=0,284 ; \chi^{2}(32)=83 ; \mathrm{p}<10^{-5} ; \Lambda$ Prime $=0,413$

Fig. 13. First Scatterplot of Canonical correlation between Neuroendocrine factors (XLine) and Entropies of Immune subsystems (Y-Line) 


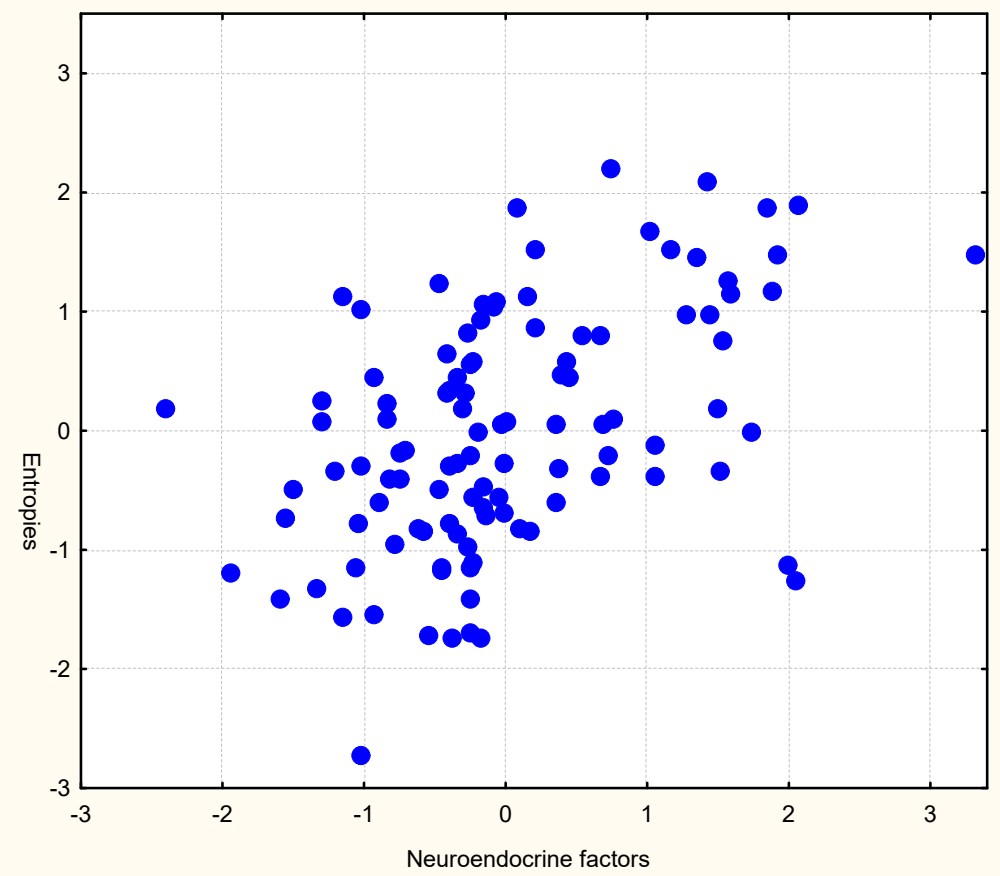

$\mathrm{R}=0,471 ; \mathrm{R}^{2}=0,222 ; \chi^{2}(21)=49 ; \mathrm{p}<10^{-3} ; \Lambda$ Prime $=0,611$

Fig. 14. Second Scatterplot of Canonical correlation between Neuroendocrine factors (X-Line) and Entropies of Immune subsystems (Y-Line)

Thus, the entropy of each of the four immune subsystems is subject to the regulatory influence of a constellation of parameters of the autonomic nervous and endocrine systems.

Using the terminology of factor analysis, we consider Entropy as a hypothetical general factor. Taking this approach, we will consider what parameters of immunity are related to the Entropy of each of the immune subsystems.

It was found that the Entropy of the Thymocytogram has an activating effect on the content in the blood of plasma cells, basophils and B-lymphocytes, as well as the content in the Splenocytogram of reticulocytes and macrophages, instead of a suppressive effect on the relative mass of the spleen and intensity of blast transformation of T-lymphocytes to phytohemagglutinin. The degree of determination of the listed parameters of immunity makes 32\% (Table 7 and Fig. $15)$. 
Table 7. Regression Summary for Immune Variables of Blood and Spleen vs Entropy TCG $\mathrm{R}=0,615 ; \mathrm{R}^{2}=0,378 ;$ Adjusted $\mathrm{R}^{2}=0,321 ; \mathrm{F}_{(10)}=6,6 ; \mathrm{p}<10^{-6}$

\begin{tabular}{|l|c|c|c|c|c|c|c|}
\hline \multicolumn{1}{|l}{} & \multicolumn{1}{|c|}{ Beta } & St. Err. & B & St. Err. & $\mathbf{t}_{(98)}$ & p-level \\
\hline Variables, Z & $\mathbf{r}$ & & Intercpt & $-0,006$ & 0,107 & $-0,06$ & 0,955 \\
\hline Plasmocytes Blood & 0,33 & 0,129 & 0,112 & 0,110 & 0,096 & 1,15 & 0,255 \\
\hline Reticulocytes Spleen & 0,29 & 0,282 & 0,095 & 0,308 & 0,104 & 2,97 & 0,004 \\
\hline Macrophages Spleen & 0,25 & 0,230 & 0,093 & 0,237 & 0,095 & 2,48 & 0,015 \\
\hline Basophiles Blood & 0,25 & $-0,114$ & 0,113 & $-0,120$ & 0,118 & $-1,01$ & 0,314 \\
\hline B-Lymphocytes Blood & 0,11 & 0,161 & 0,085 & 0,153 & 0,080 & 1,90 & 0,060 \\
\hline Blasttransformation T-Lym & $-0,28$ & $-0,393$ & 0,094 & $-0,434$ & 0,104 & $-4,17$ & $10^{-4}$ \\
\hline Spleen Mass Index & $-0,27$ & $-0,190$ & 0,098 & $-0,258$ & 0,132 & $-1,95$ & 0,054 \\
\hline Lymphocytes Spleen & $-0,23$ & $-0,122$ & 0,101 & $-0,134$ & 0,112 & $-1,20$ & 0,232 \\
\hline Leukocytes Blood & $-0,17$ & $-0,110$ & 0,092 & $-0,118$ & 0,099 & $-1,19$ & 0,236 \\
\hline
\end{tabular}

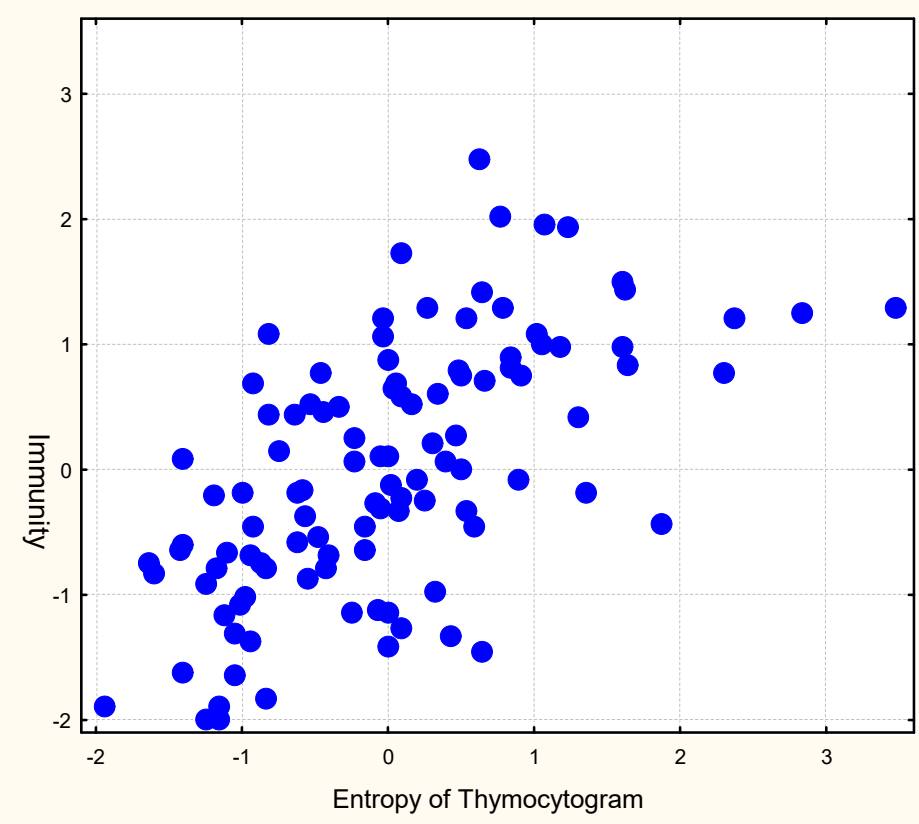

$\mathrm{R}=0,615 ; \mathrm{R}^{2}=0,378 ; \chi^{2}(9)=48 ; \mathrm{p}<10^{-6} ; \Lambda$ Prime $=0,622$

Fig. 15. Scatterplot of canonical correlation between Entropy of Thymocytogram (XLine) and parameters of Immunity (Y-Line)

The hypothetical X-factor of Splenocytogram Entropy has an even stronger immunomodulatory effect (Table 8 and Fig. 16). 
Table 8. Regression Summary for Immune Variables of Blood and Thymus vs Entropy SCG

$\mathrm{R}=0,721 ; \mathrm{R}^{2}=0,520 ;$ Adjusted $\mathrm{R}^{2}=0,460 ; \mathrm{F}_{(13)}=8,6 ; \mathrm{p}<10^{-6}$

\begin{tabular}{|l|l|l|l|l|l|l|l|}
\hline \multicolumn{1}{|l|}{} & & Beta & St. Err. & B & St. Err. & $\mathbf{t}_{\mathbf{9 5}}$ & p-level \\
\hline Variables, $Z$ & $\mathbf{Z}$ & & Intercpt & $-0,076$ & 0,086 & $-0,88$ & 0,378 \\
\hline Phagocytosis Ind Monocytes & $-0,36$ & $-0,375$ & 0,091 & $-0,342$ & 0,083 & $-4,13$ & $10^{-4}$ \\
\hline BactericidityMonocytes Blood & $-0,33$ & $-0,338$ & 0,088 & $-0,351$ & 0,092 & $-3,84$ & $10^{-3}$ \\
\hline Lymphoblastes Thymus & $-0,21$ & $-0,127$ & 0,075 & $-0,098$ & 0,058 & $-1,69$ & 0,094 \\
\hline Plasmocytes Blood & $-0,20$ & $-0,256$ & 0,087 & $-0,191$ & 0,065 & $-2,93$ & 0,004 \\
\hline Microbian Count Neutrophils & $-0,19$ & $-0,112$ & 0,084 & $-0,066$ & 0,050 & $-1,32$ & 0,190 \\
\hline Reticulocytes Thymus & $-0,18$ & $-0,108$ & 0,080 & $-0,130$ & 0,096 & $-1,35$ & 0,180 \\
\hline Macrophages Thymus & 0,19 & 0,103 & 0,091 & 0,052 & 0,046 & 1,13 & 0,263 \\
\hline Microbian Count Monocytes & 0,17 & 0,339 & 0,102 & 0,157 & 0,047 & 3,33 & 0,001 \\
\hline Segmentonucleary Neutr Blood & 0,16 & 0,298 & 0,089 & 0,326 & 0,098 & 3,33 & 0,001 \\
\hline Hassal's corpuscles Thymus & 0,15 & 0,170 & 0,080 & 0,181 & 0,085 & 2,12 & 0,037 \\
\hline Blasttransformation T-Lymphoc & 0,13 & 0,139 & 0,082 & 0,134 & 0,079 & 1,70 & 0,092 \\
\hline 0-Lymphocytes Blood & 0,11 & $-0,121$ & 0,091 & $-0,096$ & 0,073 & $-1,32$ & 0,190 \\
\hline
\end{tabular}

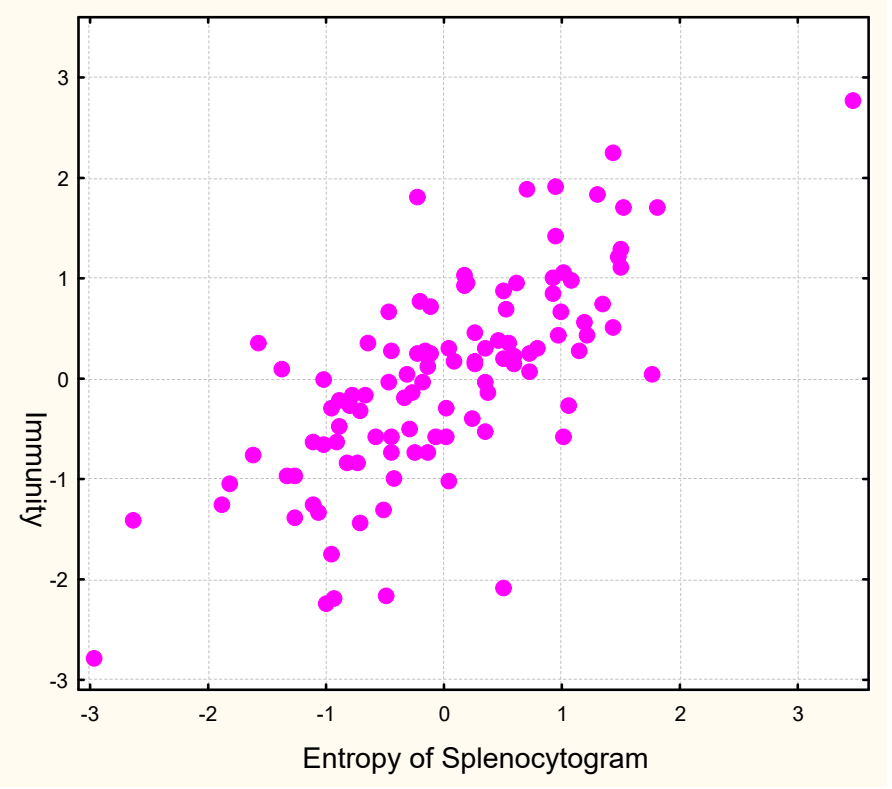

$\mathrm{R}=0,721 ; \mathrm{R}^{2}=0,520 ; \chi^{2}{ }_{(12)}=\mathbf{7 3} ; \mathbf{p}<10^{-6} ; \Lambda$ Prime $=0,480$

Fig. 16. Scatterplot of canonical correlation between Entropy of Splenocytogram (XLine) and parameters of Immunity (Y-Line)

At the same time suppressive influence prevails. In particular downregulated activity of phagocytosis of macrophages of blood and their bactericidal ability (despite increase in intensity of phagocytosis), instead of the last at microphages decreases. The content of plasma cells in the blood and lymphoblasts and reticulocytes in the thymus also downregulated. However, the Xfactor of the Splenocytogram upregulates the content in the thymus of macrophages and Gassal's 
cells, polymorphonuclear neutrophils in the blood, as well as blast transformation of $\mathrm{T}$ Lymphocytes. The degree of determination of these immune parameters by the Entropy of the Splenocytogram is $52 \%$.

The Entropy of the Immunocytogram correlates positively with the content of basophils in the blood, endotheliocytes in the Thymocytogram and lymphoblasts in the Splenocytogram, while negatively with the content of leukocytes and pan-lymphocytes in the blood, the intensity of phagocytosis of monocytes as well as spleen mass indexes and content of plasma cells in the Splenocytogram. The degree of determination of the listed immune parameters from the Entropy of the Immunocytogram makes only $29 \%$ (Table 9 and Fig. 17).

Table 9. Regression Summary for Immune Variables of Blood, Spleen and Thymus vs Entropy ICG

$\mathrm{R}=0,586 ; \mathrm{R}^{2}=0,343 ;$ Adjusted $\mathrm{R}^{2}=0,290 ; \mathrm{F}_{(9)}=6,5 ; \mathrm{p}<10^{-5}$

\begin{tabular}{|l|c|c|c|c|c|c|c|c|}
\hline \multicolumn{1}{|l|}{} & & Beta & St. Err. & B & St. Err. & t$_{\text {(99) }}$ & p-level \\
\hline Variables, Z & $\mathbf{r}$ & & Intercpt & 0,135 & 0,114 & 1,19 & 0,238 \\
\hline Basophiles Blood & 0,42 & 0,333 & 0,086 & 0,389 & 0,101 & 3,86 & $10^{-4}$ \\
\hline Endotheliocytes Thymus & 0,27 & 0,116 & 0,090 & 0,130 & 0,101 & 1,29 & 0,200 \\
\hline Lymphoblastes Spleen & 0,17 & 0,151 & 0,089 & 0,181 & 0,108 & 1,68 & 0,096 \\
\hline Microbian Count Monocytes & $-0,29$ & $-0,169$ & 0,086 & $-0,100$ & 0,051 & $-1,97$ & 0,052 \\
\hline Plasmocytes Spleen & $-0,25$ & $-0,199$ & 0,087 & $-0,265$ & 0,116 & $-2,29$ & 0,024 \\
\hline Spleen Mass Index & $-0,23$ & $-0,196$ & 0,091 & $-0,297$ & 0,138 & $-2,15$ & 0,034 \\
\hline Pan-Lymphocytes Blood & $-0,13$ & $-0,142$ & 0,085 & $-0,160$ & 0,096 & $-1,67$ & 0,098 \\
\hline Leukocytes Blood & $-0,12$ & 0,119 & 0,096 & 0,142 & 0,115 & 1,23 & 0,221 \\
\hline
\end{tabular}

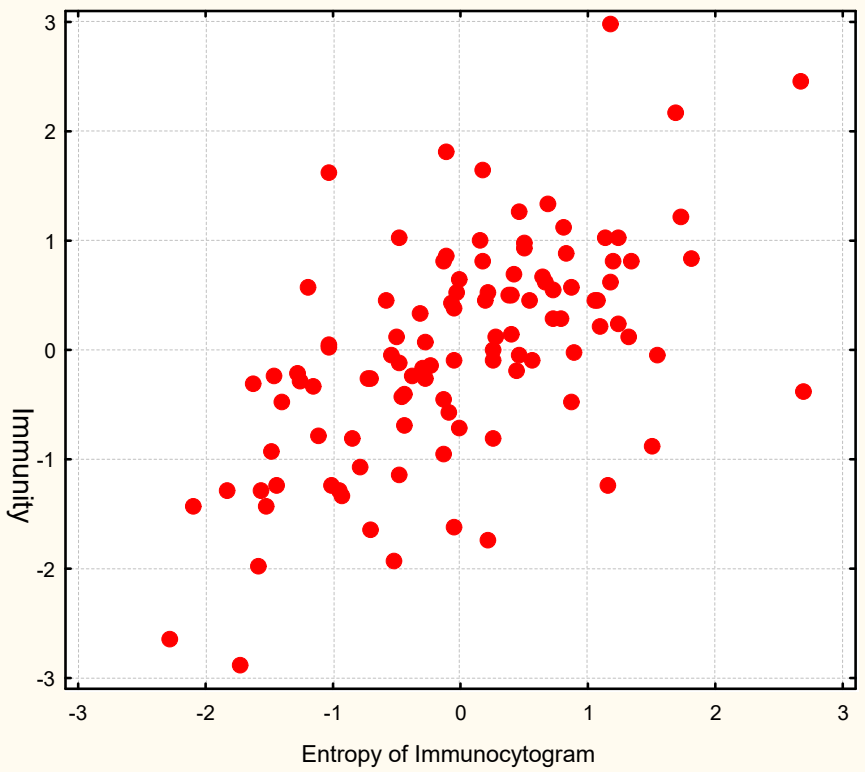

$\mathrm{R}=0,586 ; \mathrm{R}^{2}=0,343 ; \chi^{2}(8)=43 ; \mathrm{p}=10^{-5} ; \Lambda$ Prime $=0,657$

Fig. 17. Scatterplot of canonical correlation between Entropy of Immunocytogram (XLine) and parameters of Immunity (Y-Line) 
Finally, the regression model of the Entropy of the Leukocytogram includes as many as 12 immune parameters, but due to weak correlations, the degree of determination of this immune constellation is only $32 \%$ (Table 10 and Fig. 18).

Table 10. Regression Summary for Immune Variables of Blood, Spleen and Thymus vs Entropy LCG

$\mathrm{R}=0,631 ; \mathrm{R}^{2}=0,398 ;$ Adjusted $\mathrm{R}^{2}=0,322 ; \mathrm{F}_{(13)}=5,2 ; \mathrm{p}<10^{-6}$

\begin{tabular}{|l|c|c|c|c|c|c|c|}
\hline \multicolumn{1}{|c}{} & & Beta & St. Err. & B & St. Err. & $\mathbf{t}_{\text {(95) }}$ & p-level \\
\hline Variables, Z & $\mathbf{r}$ & & Intercpt & $-0,171$ & 0,129 & $-1,32$ & 0,189 \\
\hline Macrophages Spleen & 0,24 & 0,122 & 0,105 & 0,138 & 0,119 & 1,16 & 0,249 \\
\hline Natural Killers Blood & 0,18 & 0,235 & 0,086 & 0,176 & 0,065 & 2,72 & 0,008 \\
\hline Plasmocytes Blood & 0,17 & 0,198 & 0,108 & 0,186 & 0,101 & 1,84 & 0,069 \\
\hline BactericidityNeutrophils Blood & 0,16 & 0,399 & 0,109 & 0,648 & 0,177 & 3,66 & $10^{-3}$ \\
\hline BactericidityMonocytes Blood & 0,15 & 0,175 & 0,099 & 0,230 & 0,129 & 1,78 & 0,079 \\
\hline Eosinophils Spleen & $-0,19$ & $-0,130$ & 0,090 & $-0,153$ & 0,107 & $-1,43$ & 0,155 \\
\hline Killing Index Neutrophils & $-0,17$ & $-0,243$ & 0,091 & $-0,271$ & 0,102 & $-2,67$ & 0,009 \\
\hline Endotheliocytes Thymus & $-0,16$ & $-0,232$ & 0,091 & $-0,254$ & 0,099 & $-2,56$ & 0,012 \\
\hline T-cytolytic Lymphocytes & $-0,14$ & $-0,113$ & 0,101 & $-0,127$ & 0,113 & $-1,12$ & 0,265 \\
\hline Reticulocytes Spleen & $-0,13$ & $-0,152$ & 0,089 & $-0,182$ & 0,107 & $-1,70$ & 0,092 \\
\hline Leukocytes Blood & $-0,12$ & $-0,418$ & 0,119 & $-0,492$ & 0,140 & $-3,53$ & 0,001 \\
\hline Lymphoblastes Spleen & $-0,12$ & $-0,119$ & 0,105 & $-0,141$ & 0,125 & $-1,13$ & 0,260 \\
\hline
\end{tabular}

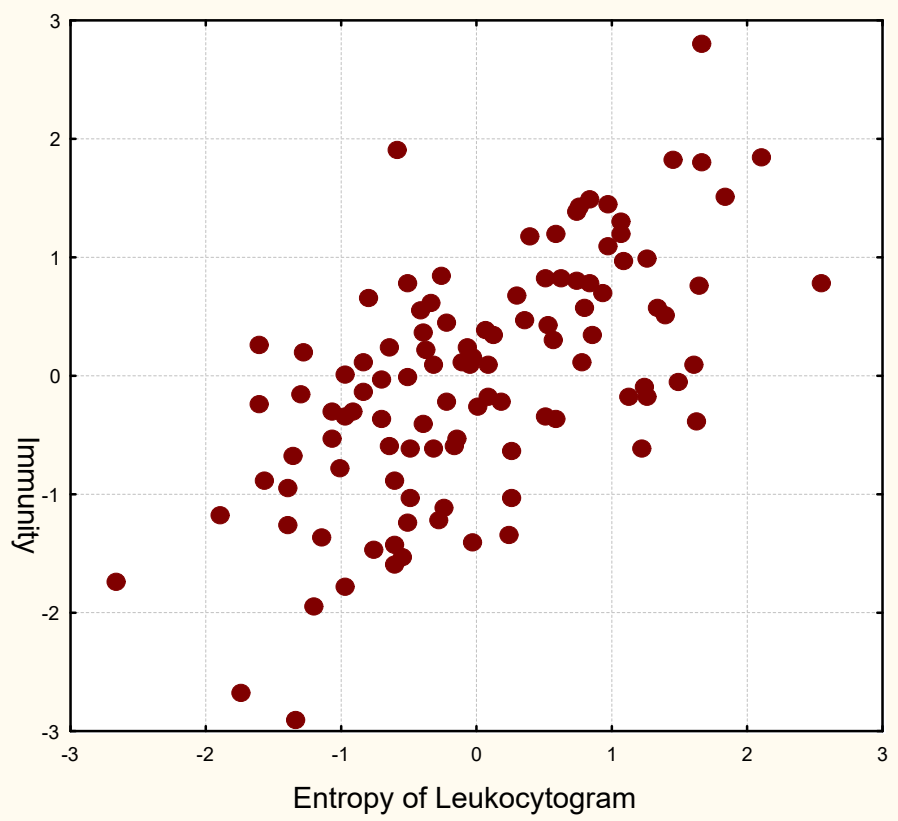

$\mathrm{R}=0,631 ; \mathrm{R}^{2}=0,398 ; \chi^{2}{ }_{(12)}=51 ; \mathrm{p}=10^{-6} ; \Lambda$ Prime $=0,602$

Fig. 18. Scatterplot of canonical correlation between Entropy of Leukocytogram (XLine) and parameters of Immunity (Y-Line) 
It is known that in mathematics Entropy is a measure of the uncertainty of a random function; in information theory it is a measure of uncertainty of the situation, any experience (test), which may have different consequences; Entropy is also a measure of disorder, the degree of chaos present in the system (quoted in: [8,9]). SE Shannon [48] linked the mathematical dependence of the concept of information and entropy, which characterizes the degree of ordering of the system. This estimate of the amount of information coincides with the estimate of the quantitative measure of eliminating the uncertainty of entropy, the degree of organization of the system.

According to PV Biloshyts'kyi [7], the mathematical formula directly indicates the possibility of quantitative change of information to change the order of the system, which in relation to biosystems can mean a change in quality (sustainability, performance, health, etc.) and thus indicate the purposeful use of bioinformation in medical practice. Occasionally, the author proposes to use the term reliability of the functioning of the organism instead of the term Entropy, which is very impressive to us, as well as his assumption that the dependence of the reliability of the biosystem on information is elusive vis vitalis.

In our humble opinion, we have been able to demonstrate that Entropy has real life force, which is quantified by the canonical correlation coefficient of Entropy levels of morphofunctional immune subsystems with the immunity parameters of other subsystems. That is, Entropy is the subject of influence. On the other hand, Entropy is an object that is subject to the regulatory influence of the autonomic nervous and endocrine systems. Neuroendocrine-immune relatioships in rats are analyzed in detail in our previous studies [15,27,28,41,42].

\section{CONFORMITY TO ETHICAL STANDARDS}

Experiments on animals have been carried out in accordance with the provisions of the Helsinki Declaration of 1975, revised and supplemented in 2002 by the Directives of the National Committees for Ethics in Scientific Research.

The carrying out of experiments was approved by the Ethics Committee of the Horbachevskyi Ternopil' State Medical University. The modern rules for the maintenance and use of laboratory animals complying with the principles of the European Convention for the Protection of Vertebrate Animals used for scientific experiments and needs are observed (Strasbourg, 1985).

\section{REFERENCES}

1. Babelyuk VYe, Popadynets' OO, Dubkova GI, Zukow W, Muszkieta R, Gozhenko OA, Popovych IL. Entropy of gas-discharge image correlates with the entropies of EEG, immunocytogram and leukocytogram but not HRV. Pedagogy and Psychology of Sport. 2020; 6(2): 30-39.

2. Baevskiy RM, Ivanov GG. Heart Rate Variability: theoretical aspects and possibilities of clinical application [in Russian]. Ultrazvukovaya i funktsionalnaya diagnostika. 2001; 3: 106-127.

3. Bazarnova MA. Cytology investigation punctates spleen. In: Guide to practical training in clinical laboratory diagnostics [in Russian]. Kyiv: Vyshcha shkola; 1988: 263-264.

4. Belousova OI, Fedotova MI. Comparative data on changes in spleen, thymus and bone marrow lymphocyte counts in the early post-irradiation period over a wide range of doses [in Russian]. Radiobiology-Radiotherapy. 1968; 9(3): 309-313.

5. Bianco C. Population of lymphocytes bearing a membrane receptor for antigen-antibody complex. J Exp Med. 1970; 134(4): 702-720. 
6. Bilas VR, Popovych IL. Role of microflora and organic substances of water Naftussya in its modulating influence on neuroendocrine-immune complex and metabolism [in Ukrainian]. Medical Hydrology and Rehabilitation. 2009; 7(1): 68-102.

7. Biloshytskyi PV. Temperature, Information, Water, Anabiosis, Immortality [in Ukrainian]. Health and Longevity. Kyiv; 2007: 46-47.

8. Biloshytskyi PV, Biloshytskyi SP. Astrogeophysical aspects of bioinformation. [in Ukrainian]. Cosmos and the Biosphere. Partenit; 2003: 131-132.

9. Biloshytskyi PV, Biloshytskyi SP, Klyuchko OM. Conceptual Foundations of Bioinformation [in Ukrainian]. Cosmos and the Biosphere. Partenit; 2005: 141-142.

10. Chebanenko OI, Popovych IL, Chebanenko LO. Introduction to Information Balneology. Influence of Bioactive Water Naftussya of Truskavets' Spa on Information Components of Neuroendocrineimmune Complex and Metabolism [in Ukrainian]. Kyiv: UNESCO-SOCIO; 2011: 373 c.

11. Fil' VM. Amelioration of "Truskavetsian" water with aloe extract [in Ukrainian]. Medical Hydrology and Rehabilitation. 2008; 6(1): 156-162.

12. Flyunt IS, Chebanenko LO, Chebanenko OI, Kyjenko VM, Fil' VM. Experimental balneophytotherapy [in Ukrainian]. Kyiv: UNESCO-SOCIO; 2008: 196 p.

13. Goryachkovskiy AM. Clinical biochemi [in Russian]. Odesa: Astroprint; 1998: 608 p.

14. Gozhenko OA, Zavidnyuk YV, Korda MM, Mysula IR, Klishch IM, Zukow W, Popovych IL. Features of neuro-endocrine and immune reactions to various water-salt loads in female rats. Journal of Education, Health and Sport. 2018; 8(9): 11-31.

15. Gozhenko AI, Zukow W, Polovynko IS, Zajats LM, Yanchij RI, Portnichenko VI, Popovych IL. Individual Immune Responses to Chronic Stress and their Neuro-Endocrine Accompaniment. RSW. UMK. Radom. Torun; 2019: 200 p.

16. Huchko BYa. Immune accompaniment of polyvariant post-stress changes in blood plasma atherogenicity in rats [in Ukrainian]. Medical Hydrology and Rehabilitation. 2008; 6(4): 73-83.

17. Instructions for the use of a set of reagents for the enzyme-linked immunosorbent assay in human serum. St. Petersburg: Alkor Bio CJSC; 2000: 50 p.

18. Jondal M, Holm G, Wigzell H. Surface markers on human T and B lymphocytes. I. A large population of lymphocytes forming nonimmune rosettes with sheep red blood cells. J Exp Med. 1972. 136;(2): 207-215.

19. Khaitov RM. Physiology of the Immune System [in Russian]. Moskwa: VINITI RAS; 2005: 428 p.

20. Kostyuk PG, Ivassivka SV, Fil' VM, Il'nyts'ka-Rybchych TO, Kyjenko VM, Flyunt IS. Physiological Activity of the Health Drink "Truskavetsian Crystal with Aloe" [in Ukrainian]. Drohobych. Posvit; 2007: 144 p.

21. Kozyavkina OV, Kozyavkina NV, Gozhenko OA, Gozhenko AI, Barylyak LG, Popovych IL. Bioactive Water Naftussya and Neuroendocrine-Immune Complex [in Ukrainian]. Kyiv: UNESCOSOCIO; 2015: 349 p.

22. Kul'chyns'kyi AB, Gozhenko AI, Zukow W, Popovych IL. Neuro-immune relationships at patients with chronic pyelonephrite and cholecystite. Communication 3. Correlations between parameters EEG, HRV and Immunogram. Journal of Education, Health and Sport. 2017; 7(3): 53-71.

23. Kyrylenko IG, Flyunt I-SS, Fil' VM, Zukow W, Popovych IL. Changes in electrokinetic index of buccal epithelium correlated with changes in some parameters of immunity and fecal microbiocenosis. Journal of Education, Health and Sport. 2018; 8(10): 168-170.

24. Limatibul S., Shore A., Dosch H.M., Gelfand E.W. Theophylline modulation of E-rosette formation: an indicator of T-cell maturation. Clin Exp Immunol. 1978; 33(3): 503-513.

25. Lukyanchenko OI, Gozhenko OA, Mel'nyk OI, Zukow W, Popovych IL. Features of the immune profile and microbiota in persons whose immune status is susceptible or resistant to chronic stress. Journal of Education, Health and Sport. 2019; 9(3): 601-611.

26. Perederiy VG, Zemskov AM, Bychkova NG, Zemskov VM. Immune status, principles of its evaluation and correction of immune disorders [in Russian]. Kyiv: Zdorovya; 1995: 211 p. 
27. Polovynko IS, Zajats LM, Popovych AI, Popovych IL. Integral quantification of neuroendocrine and immune responses to chronic stress in male rats [in Ukrainian]. In: Pathophysiology and Pharmacy: ways of integration: Abstracts VII National Congress pathophysiologists Ukraine with international participation (5-7 October 2016). Kharkiv: NPhU, 2016: 182.

28. Polovynko IS, Zayats LM, Zukow W, Popovych IL. Neuro-endocrine-immune relationships by chronic stress at male rats. Journal of Health Sciences. 2013; 3(12): 365-374.

29. Polovynko IS, Zajats LM, Zukow W, Yanchij RI, Popovych IL. Quantitative evaluation of integrated neuroendocrine and immune responses to chronic stress in rats male. Journal of Education, Health and Sport. 2016; 6(8): 154-166.

30. Polovynko IS, Zukow W. Variety of immune responses to chronic stress in rats male. Journal of Education, Health and Sport. 2016; 6(12): 843-856.

31. Popadynets' OO. Factor analysis of the information field of parameters of nervous regulatory structures and immunity. Focus on their entropy [in Ukrainian]. Bulletin of Marine Medicine. 2020; 2(87): 7-18.

32. Popadynets' OO, Gozhenko AI, Zukow W, Popovych IL. Relationships between the entropies of EEG, HRV, immunocytogram and leukocytogram. Journal of Education, Health and Sport. 2019; 9(5): 651-666.

33. Popadynets' OO, Gozhenko AI, Zukow W, Popovych IL. Interpersonal differences between of the entropies of EEG, HRV, immunocytogram and leukocytogram. Journal of Education, Health and Sport. 2019; 9(6): 534-545.

34. Popadynets' OO, Gozhenko AI, Zukow W, Popovych IL. Peculiarities of spectral parameters of EEG, HRV and routine parameters of immunity in patients with various levels of the entropy of EEG, HRV, immunocytogram and leukocytogram. Journal of Education, Health and Sport. 2019; 9(8): 617-636.

35. Popadynets' OO, Gozhenko AI, Badiuk NS, Zukow W, Kovbasnyuk MM, Korolyshyn TA, Popovych IL. Relationships between changes in entropy of the EEG and parameters of the immunity. Pedagogy and Psychology of Sport. 2020; 6(1): 24-40.

36. Popadynets' O, Gozhenko A, Badyuk N, Popovych I, Skaliy A, Hagner-Derengowska M, Napierata M, Muszkieta R, Sokołowski D, Zukow W, Rybałko L. Interpersonal differences caused by adaptogen changes in enropies of EEG, HRV, immunocytogram, and leukocytogram. Journal of Physical Education and Sport. 2020; 20(Suppl. 2): 982-999.

37. Popovych AI. Features of the immunotropic effects of partial components of the balneotherapeutic complex of spa Truskavets'. Journal of Education, Health and Sport. 2018; 8(12): 919-935.

38. Popovych IL. Information effects of bioactive water Naftyssya in rats: modulation entropic, prevention desynchronizing and limitation of disharmonizing actions water immersion stress for information components of neuro-endocrine-immune system and metabolism, which correlates with gastroprotective effect [in Ukrainian]. Medical Hydrology and Rehabilitation. 2007; 5(3): 50-70.

39. Popovych IL. Stress-limiting effects of bioactive Naftussya water under chronic restrictive stress in rats [in Ukrainian]. Medical Hydrology and Rehabilitation. 2008; 6(3): 128-153.

40. Popovych IL. Influence of balneotherapy at Truskavets' spa on adaptive-protective systems of persons with disadaptosis and immunodysfunction [in Ukrainian]. Medical Hydrology and Rehabilitation. 2009; 7(2): 71-87.

41. Popovych IL. Stresslimiting Adaptogene Mechanism of Biological and Curative Activity of Water Naftussya [in Ukrainian]. Kyiv: Computerpress; 2011: 300 p.

42. Popovych IL, Gozhenko AI, Zukow W, Polovynko IS. Variety of Immune Responses to Chronic Stress and their Neuro-Endocrine Accompaniment. Scholars' Press. Riga; 2020: 172 p.

43. Popovych IL, Gumega MD, Verba IE, Popovych AI, Korolyshyn TA, Tkachuk SP, Ostapenko VM, Zukow W. Comparative investigation effects on nervous and immune systems of bioactive water Naftussya spa Truskavets' and stable water solution of Boryslav's ozokerite. Journal of Education, Health and Sport. 2016; 6(4): 364-374. 
44. Popovych IL, Kul'chyns'kyi AB, Korolyshyn TA, Zukow W. Interrelations between changes in parameters of HRV, EEG and cellular immunity at patients with chronic pyelonephritis and cholecystitis. Journal of Education, Health and Sport. 2017; 7(10): 11-23.

45. Popovych IL, Kul'chyns'kyi AB, Gozhenko AI, Zukow W, Kovbasnyuk MM, Korolyshyn TA. Interrelations between changes in parameters of HRV, EEG and phagocytosis at patients with chronic pyelonephritis and cholecystitis. Journal of Education, Health and Sport. 2018; 8(2): 135156.

46. Popovych IL, Polovynko IS, Zajats LM, Mel'nyk OI. Sexual dimorphism of the neuroendocrineimmune complex and its reactions on chronic stress at rats. Experimental and Clinical Physiology and Biochemistry. 2018; 3(83): 5-17.

47. Popovych IL, Sydoruk NO, Gozhenko AI, Zukow W. Modulating effects of bioactive water Naftussya from layers Truskavets' and Pomyarky on neuro-endocrine parameters at humans with dysadaptation. Journal of Education, Health and Sport. 2017; 7(2): 465-478.

48. Shannon CE. Works on the theory of informatics and cybernetics. Moskwa: Inostrannaya literatura; 1963: $329 \mathrm{p}$.

49. Struk ZD, Mel'nyk OI, Zukow W, Popovych IL. The diversity of immune reactions to balneotherapy and their accompaniments. Journal of Education, Health and Sport. 2019; 9(11): 349-373.

50. Sydoruk NO, Chebanenko OI, Zukow W, Popovych IL. Comparative Study of Physiological Activity of Naftussya Water Truskavets' and Pomyarky Deposits [in Ukrainian]. Kyiv. UNESCO-SOCIO; 2018: $176 \mathrm{p}$.

51. Yushkovs'ka OG. Using information theory to study adaptive responses in the body athletes [in Ukrainian]. Medical Rehabilitation, Kurortology, Physiotherapy. 2001; 1(25): 40-43.

52. Zajats LM, Polovynko IS, Zukow W. Features neuro-endocrine support diversity of immune responses to chronic stress in male rats. Journal of Education, Health and Sport. 2017; 7(3): 97-105.

53. Zajats LM, Polovynko IS, Zukow W, Yanchij RI,. Mysakovets' OG, Mel'nyk OI, Hrytsak YaL. Neuroendocrine-immune relatioships in rats females. Journal of Education, Health and Sport. 2017; 7(10): 59-78.

54. Zavidnyuk YV, Mysula IR, Klishch IM, Zukow W, Popovych IL, Korda MM. General non-specific metabolic, neuroendocrine and immune reactions to various water-salt loads in female rats. Journal of Education, Health and Sport. 2018; 8(3): 513-524.

55. Zukow W, Popadynets' OO, Gozhenko AI, Popovych IL. Interpersonal differences in parameters of the EEG and HRV in the humans with various levels of the entropy of the EEG, HRV, immunocytogram and leukocytogram. Journal of Education, Health and Sport. 2019; 9(7): 448-466. 